\title{
Strmim stazama politologa Daga Strpića u čitanju Marxa
}

\author{
DRAGUTIN LALOVIĆ \\ Fakultet političkih znanosti, Sveučilište u Zagrebu
}

\begin{abstract}
Sažetak
U tekstu se prikazuju i vrednuju glavne odlike znanstvenog pristupa, načina argumentacije i mogućih analitičko-istraživačkih i razvojno-općedruštvenih dosega Strpićeve teorijske ostavštine kada je riječ o njegovu fundamentalnom istraživanju Marxove epohalne kritike političke ekonomije, ponajprije u knjizi Robna proizvodnja i udruženi rad u Marxovoj kritici političke ekonomije (2017/1991). Najprije se predstavlja inicijalni Strpićev istraživački program suvremenoga marksovskog dovršavanja i razvijanja Marxove "Kritike" (1982). U središtu izlaganja sažeto su prikazani glavni elementi Strpićeva čitanja Marxove kritike političke ekonomije. Prvo, ocjena Marxove recepcije klasične britanske političke teorije i političke ekonomije, kao i recepcije te baštine u Hegelovoj filozofiji. Drugo, rekonstrukcija logike Marxova kategorijalnog aparata kao apstraktne sfere "kapitala općenito", u razlici spram konkretne sfere konkurencije "mnogih kapitala", a unutar tog polja primjereno određenje "robe općenito" kao logičkog polazišta cjelokupnoga teorijskog sustava i vrijednosti kao zakona kretanja tržišnih cijena. Treće, primjereno je Kapitalu pristupiti iz dinamičke perspektive teorije socijetalnih ciklusa i cikličkoga razvoja; iz tendencijskih zakona povijesnog razvoja kapitalističke akumulacije valja razumjeti strukturu kapitala kao društvenog procesa proizvodnje, prometa i reprodukcije. Četvrto, razlikovanje marksovskoga (znanstvenog i kritičkog) od marksističkoga (ideologijskog i klasno zasnovanog) pristupa kritici političke ekonomije. Zatim se pomno prikazuje i kritički vrednuje Strpićevo intrigantno shvaćanje dvojstva klasičnih političkih teorija, koje se, po njegovu sudu, očituje kao razlikovanje između Machiavellijeve "politikologije", koja politiku shvaća u kategorijama vlasti i vladanja, i Hobbesove "politologije", kao sistematske znanosti o građanskoj zajednici. U tom se sklopu problematizira Strpićevo hobsističko politologijsko razumijevanje Marxa. Završno se pokušavaju dokučiti razlozi Marxova sustajanja u dovršavanju projekta kritike političke ekonomije, što njegove interprete suočava $\mathrm{s}$ jedva premostivim teorijskim poteškoćama $\mathrm{u}$ nastojanju da se Marxovo znanstveno nasljeđe razvija do moguće osnove suvremenih teorijskih i empirijskih istraživanja temeljnih problema našeg vremena.
\end{abstract}

Ključne riječi: kritika političke ekonomije, politologija, marksizam, Marx, Hobbes, Strpić 
Nema široka druma koji vodi u znanost, i samo oni koji se ne plaše umora od pentranja po njezinim strmim stazama imaju izgleda da se popnu na njezine svijetle visove.

Marxovo pismo građaninu Mauriceu La Chârtreu, 18. ožujka 1872.

Osnovicu za cjelovito i kritičko vrednovanje teorijske ostavštine vrhunskog politologa i polit-ekonomista Daga Strpića općenito, a njegova čitanja Marxa posebno, tvori prvenstveno njegova temeljna studija Robna proizvodnja i udruženi rad $u$ Marxovoj kritici političke ekonomije (2017/1991), ali uključuje barem još i knjige Karl Marx i politička ekonomija Moderne (2010) i Prema Novoj političkoj ekonomiji (2015). Preliminarno bi pritom valjalo uvažiti i njegove "rane radove" iz razdoblja od 1975. do 1988, koji svjedoče o Strpićevu sustavnom istraživanju, kritičkoj rekonstrukciji i teorijskom razvijanju marksovskoga kategorijalnog aparata kritike političke ekonomije. ${ }^{1}$

\section{Suvremeno marksovsko dovršavanje i razvijanje Marxove "Kritike"}

Tri su teksta iz korpusa ranih radova ključna za prikazivanje i razumijevanje temporalne dimenzije razvijanja i ukupnih dosega Strpićeva istraživačkog programa “čitanja Marxa” (1982, 1986a, 1989).

Najraniju verziju istraživačkog programa proučavanja Marxove kritike političke ekonomije (u daljem tekstu "Kritike") nalazimo u njegovoj samosvjesnoj intervenciji na velikom jugoslavenskom skupu iz 1981. godine na temu "Aktualnost Marxovog Kapitala”. Ustvrdivši da je sudbina Marxova kapitalnog djela, od samog početka, u znaku permanentne interpretativne regresije (pojedostavnjivanja, nerazumijevanja, čak i neodobravanja) u odnosu na izvornu teorijsko-revolucionarnu intenciju "Kritike", Strpić ipak smatra da i s tako reduciranim značenjem u tzv. marksizmu (a zapravo engelsizmu) Kapital ostaje "najznačajnijim djelom društvene teorije posljednja dva desetljeća". Ta je interpretativna regresija Kapitala dijelom proistjecala iz njegove nedovršenosti, a dijelom iz njegove "nedešifrirane metodologije". Strpić upućuje na razloge (niz tadašnjih istraživanja o utemeljenosti Marxova djela u klasičnoj političkoj ekonomiji i klasičnoj političkoj teoriji) koji, po njegovu sudu, upućuju na zaključak da bi "doba regresije interpretativne valorizacije 'Kapitala' moglo biti na izmaku'. U prilog takvom uvjerenju navodi djelo Ernesta Mandela Kasni kapitalizam (1981/1972), za koje ocjenjuje da je uspjelo

1 Posebnu bi pozornost zasluživali njegovi brojni radovi iz tog razdoblja u kojima konkretizira i primjenjuje marksovski kategorijalni aparat u analizi kako samoupravnog projekta (napose 1975a, 1976, 1984, 1985b) tako i zbiljske anatomije jugoslavenskoga samoupravnog tranzicijskog društva (napose 1983a, 1983b, 1983c, 1985a, 1988b, 1988c). 
“empirijski dokazati primjenjivost Marxova aparata, takvog kakav je dan u 'Kapitalu', na istraživanje globalnog razvitka reprodukcije kapitala u svijetu i pojedinim zemljama". Stoga je "neodložna zadaća marksista" kategorijalni aparat "Kritike" "dalje razviti Marxovim načinom", marksovskim načinom započeti posao autentičnog dovršavanja Marxova nedovršenog djela. Pri čemu je preliminarno nužno da "konačno počnemo čitati 'Kapital' onako kako ga je Marx pisao i kako ga je mislio. Uz nezaobilazno kritičko preispitivanje njegove literature i cijele tradicije iz koje ta literatura izlazi, kao i njegovog recipiranja te literature i te tradicije" (Strpić, 1982: $135,138,146,147)$.

Dalje preciziranje i razvijanje Strpićeva istraživačkog programa nudi nam njegov tekst "U potrazi za teorijskom osnovom (Za izradu analitičkog instrumentarija istraživanja ekonomskih zakonitosti)" (1986). Prema Strpićevoj dijagnozi suvremenog stanja "opće ekonomske teorije", ekonomska analiza se u načelu odvaja od svoga ishodišnog principa, od "teorije vrijednosti kao metodičke i metodološke spone znanosti o zajednici u cjelini i ekonomske analize". Koliko god pritom bio nedvojben znanstveni doprinos raznih autora i pravaca polit-ekonomskog i ekonomskog mišljenja (od Keynesa preko Schumpetera i Hayeka do Friedmana, za kojega se tvrdi da je "donio današnji prevrat u modernoj građanskoj političkoj i ekonomskoj teoriji”), ipak se s marksovskog stajališta može ustvrditi da je svima zajedničko to da "zaobilaze (iako u temelju liberalnu) teoriju vrijednosti kao nedokazivu, izlišnu i neproduktivnu, apstraktnu teorijsku konstrukciju koja ne može doprinijeti ni analitičkom ni poslovnom ili političkom rješavanju aktualnih političkih problema". Retrogradni pak razvoj marksističke ekonomske teorije, izveden iz "engelsovske recepcije Marxove kritike političke ekonomije" (historicističko razumijevanje robe, a nerazumijevanje imanentne robne dijalektike), svjedoči o redukciji izvornog projekta na "pojednostavljeni, historizirani i sociologizirani - rikardovski ili čak predrikardovski predložak Marxove kritike političke ekonomije". Unatoč tom fatalnom trendu bilo je i u nas mjestimice "značajnih teorijskih prodora" da se iz te neplodne tradicije izađe, o čemu primjerice svjedoče neki najbolji radovi V. Bakarića (v. Strpić, 1984). Filozofijske reinterpretacije značajnih mislilaca (kao što su Lukácseva, Marcuseova, Blochova), unatoč svim njihovim misaonim dosezima, bile su ipak ozbiljnom epistemologijskom zaprekom za izvorno čitanje i istraživanje Marxova djela kao "epohalne imanentne kritike političke ekonomije" (i kao znanstvene kritike teorijskog sustava i kao praktičke kritike zbiljskoga građanskog društva). Umjesto filozofijskoga izvanjskog čitanja Marxove "Kritike" Strpić se u svojem istraživačkom projektu oslanja na radove R. Rosdolskog (1975/1968), H. Reichelta (1970), H.-G. Backhausa (1976/1969) i W. Schwarza (1978) u zagovoru izravnog čitanja Marxove "Kritike”, "uz višestruko i višestrano provjeravanje eksplicitnog ili impliciranog polit-ekonomskog polja važenja ključnih Marxovih kategorija". 
Iz jezgrovita obrazloženja istraživačkog programa izravnog čitanja Marxova djela izdvajam središnji dio argumentacije:

Umjesto mehaničkog apliciranja logike jednostavnog prometa na pojave s "površine" društva na konkurenciju mnogih kapitala - kako to mahom čini politička ekonomija - Marx u "postupku istraživanja" svoje "Kritike" izdvaja općenite ekonomske zakonitosti reprodukcije kapitala u cjelini-u posebnu "sferu", sferu "kapitala općenito". Da bi, nakon dijalektičkog izvođenja u njihovu izravnom obliku... - razvijene kroz mnoga posredovanja i općenito konkretizirane, iznova mogao te zakonitosti vratiti u njihov "izvrnut" oblik, u sferu "konkurencije".

Dijalektičko izvođenje/"izlaganje" kapitala općenito započinje $i$ utemeljeno je analizom "robe općenito" - kao pripadne upravo toj sferi. Ali Marxu je roba istodobno i posredovni moment konkurencije "mnogih" pojedinačnih kapitala, realni elementarni oblik građanskog bogatstva. A i metodološki instrument cijele ove logičke operacije i operacije svakog daljnjeg metodičkog prijelaza na novu razinu izvođenja (odnosno procesiranja) - od elementarnih materijalnih, preko ideoloških i historijskih formi građanske zajednice, i opet natrag, povratnim djelovanjem sistema u cjelini na svaku njegovu kategoriju, do pune logičke, vremenske i prostorne konkretizacije.

Takvo obrazloženje, ovdje posve sažeto (v. Strpić, 1986a: 76-84), pokazuje da je Strpić tada ovladao svim glavnim istraživačkim dosezima svojeg izravnog čitanja Marxove kritike političke ekonomije, koji će 1991. godine biti u cijelosti izloženi u velikoj sintetičkoj studiji Robna proizvodnja i udruženi rad u Marxovoj kritici političke ekonomije.

Treće, u teorijski superiornoj studiji "Tržišna ili robna formacija/proizvodnja društva?" (1989) očituje se Strpićeva puna samosvijest u dostojnom kritičkom dijalogu sa Jacquesom Bidetom i njegovim reutemeljenjem Marxove teorije u Što da se radi s "Kapitalom"? (1988/1985). O tome sam podrobno referirao u svojem pogovoru Strpićevoj knjizi (v. Lalović, 2017a: 443-451); ovdje samo ističem najvažniji Strpićev uvid da je tek barem načelnim dovršenjem cjeline sustava svoje "Kritike" Marx mogao najzad primjereno pojmiti i precizirati karakter "robe općenito" kao polazišnoga najapstraktnijeg momenta izlaganja, kao jedinoga koji imanentnom logikom konkretizacije analize epohalnog sklopa omogućuje i prekoračenje obzora vječnog vraćanja kapitalskog načina proizvodnje života (v. Strpić, 1989).

\section{Glavni elementi Strpićeva čitanja Marxove kritike političke ekonomije}

Iz mojeg pogovora "Marxovo nasljeđe kao zadaća mišljenja" (Lalović, 2017a) u ovom odjeljku izdvajam i sažimam nekoliko točaka, uz dodatne izvode i napomene, o Strpićevu teorijskom čitanju Marxa. 
1. Smisao Marxove "Kritike" moguće je dokučiti samo iz poznavanja cjeline klasične političke i političko-ekonomske teorije kao teorije moderne građanske zajednice (počevši od Hobbesa kao utemeljitelja).

Po temeljnoj autorovoj tezi, istraživanja klasične moderne teorije (britanske političke teorije i političke ekonomije) i danas su vrlo aktualna. Ne samo zato što još uvijek ima interpretativno neotkrivenih aspekata teorija Karla Marxa, Adama Smitha i Thomasa Hobbesa (kojima se najviše bavio) nego i zato što je po njegovu sudu struktura moderne epohe koju su oni razotkrivali još uvijek u velikoj mjeri regulativna za suvremene svjetske i nacionalne političke, društvene i ekonomske poretke. Stoga onda o njezinu razumijevanju umnogome ovisi i njihovo današnje uspješno funkcioniranje i daljnji razvoj.

Nužno je istražiti i pojmiti kako se Marx teorijski sučeljava s Hegelovom sintezom klasične političke i političko-ekonomske teorije. Već u tzv. Pariškim rukopisima (1844) Marx uviđa da Hegel u Fenomenologiji duha stoji na stajalištu klasične političke ekonomije, jer rad poima kao temelj proizvodnje moderne zajednice. Pritom nije toliko riječ o Marxovu kritičkom preuzimanju i materijalističkom razvijanju spekulativne dijalektike (kategorije totaliteta, posredovanja, ukidanja/prevladavanja, preobrazbe oblika, bitka, biti i pojave, društva kao procesa) koliko o načinu na koji je Hegel u Filozofiji prava spekulativno recipirao i u svoje shvaćanje "građanskog društva" ugradio temeljne uvide klasične političke ekonomije (napose Smithove).

Strpićevo kritičko čitanje Marxa, u njegovu suočavanju s Hegelom i s britanskom velikom tradicijom, sadrži metodički odlučujuće upozorenje da za razumijevanje i tumačenje Marxa nije toliko bitan njegov odnos spram Hegela koliko su bitni "klasični autori Hobbes, Locke, Hume, Smith koji su na razvoj znanosti utjecali više od obojice" (Strpić, 2017: 16).

Naime ti su klasični autori formirali znanstvenu paradigmu unutar koje su se morali kretati i Hegel i Marx. No Marx nije uspio dovršiti svoj teorijski projekt, pa stoga nije mogao uspjeti ni u svojem pokušaju kritičkog prevladavanja te tradicije, nije do kraja uspio razjasniti svoj odnos ni spram Hegela ni spram Smitha. Po Strpićevu zaključnom sudu, Marxova se metodološka tragedija očituje u izbjegavanju da "sustavno i sebi i publici položi računa o vlastitim neposrednim teorijskim prethodnicima, Smithu, Ricardu i Hegelu, o svojem odnosu spram njih i njihovih metoda te o vlastitoj metodi i metodologiji u cjelini" (ibid.: 274).

2. Odlučujuće je prepoznavanje i preciziranje kategorijalnog polja Kapitala kao bitne apstraktne sfere "kapitala općenito" u razlici spram konkretne pojavne sfere "mnogih kapitala u konkurenciji". U tom je polju "roba općenito" legitimno polazište izlaganja teorije, ali ujedno i njezinih temelja i rezultata, kao i same zbiljnosti kapitalskog načina proizvodnje. Polazište nije tržište, jer ono zatvara u dani epo- 
halni građanski sistem. Samo ako je roba pojmljena kao kapitalska roba može se dokučiti ne samo logika funkcioniranja nego i imanentnog samoprevladavanja kapitalskog načina proizvodnje života. Dakle metodologijski je ključna izvedba robe kakva je moguća samo pod pretpostavkom razvijenoga kapitalskog tržišta, te poimanje uvjeta prelaska načina proizvodnje kapitala, privatnog vlasništva i kapitalske podjele rada koja sebi podređuje kombiniranoga radnika - u povijesno tek po kapitalu latentni udruženi način proizvodnje.

Dvije su Strpićeve nezaobilazne inovacije u razumijevanju marksovskog teorijskog polja: pojmovno određenje polit-ekonomskih kategorija "vrijednost" i "roba".

Marx je, po Strpićevu pomno obrazloženom sudu, upravo genijalan kao analitičar vrijednosti, zato što vrijednost ne shvaća kao "neposredno svojstvo robe, kako su je shvaćali klasičari", nego kao zakon kretanja cijena u zbiljskom tržišnom procesu: "vrijednost (je) pokretački zakon oscilatorne dinamike cijena, a ne numerička ili fizička veličina na koju bi ih trebalo svoditi u političkoj ekonomiji" (ibid.: 191). ${ }^{2}$ Vrijednost ne samo da nije svojstvo robe nego je "normala normale (cijene proizvodnje) koja se formira odstupanjem tržišnih cijena od normale što nije unaprijed zadana, već nastaje upravo tim odstupanjem" (ibid.: 273). Vrijednost se može razumjeti ne kao supstancija materijalizirana u robi, nego isključivo kao "zakon kretanja kroz koje prolaze cijene, posredovan trendovima normalnih produkcijskih cijena kao ex post reakcijama na konkretna tržišna cjenovna odstupanja od (naknadnih!) normala" (ibid.: 335). Vrijednost se može pojmiti samo iz cjeline teorijskog sustava, iz cjelokupnog kretanja proizvodnje, prometa i reprodukcije društvenog kapitala.

Strpić kritički konstatira kako je takvo tumačenje teorije ili zakona vrijednosti "nedovoljno uzimano u obzir u marksizmu" i uopće u tumačenjima Marxa. Više od toga, "nikad dosad... nije zabilježena čak ni ozbiljnija orijentacija ekonomista marksističke provenijencije na istraživanje odstupanja od vrijednosti i produkcijskih cijena - kao pravog oblika djelovanja zakona vrijednosti prema Marxovu shvaćanju" (ibid.: 191-192).

Najveća je poteškoća u razumijevanju te teorije vrijednosti u tome što se ona nije mogla do kraja dokazati na razini analize apstraktne sfere "kapitala općenito", nego je izvedbu kategorija trebalo izvesti do kraja, do konkretne razine sfere mnogih kapitala u konkurenciji. Do te razine Marxovo istraživanje nije dospjelo, teorijski je sustav ostao nedovršen, pa je i razumijevanje ključne kategorije vrijednosti,

${ }^{2}$ U osloncu na Hegela, Marx dijalektički obrazlaže svoje poimanje vrijednosti u Grundrissima, iz kojih Strpić navodi in extenso "briljantni pasaž", no koji ovdje ne možemo prenijeti u cijelosti. Tako Marx ustvrđuje da se tržišna vrijednost nikad ne izjednačava s realnom vrijednošću, ne izražava se, "kao što bi rekao Hegel, apstraktnom identičnošću već neprestanom negacijom negacije same sebe kao negacije realne vrijednosti... vrijednost se pojavljuje kao zakon kretanja kroz koji prolaze cijene” (Marx, 1979: 46-47; istaknuo D. L.; v. Strpić, 2017: 191). 
izvedive samo iz cjeline sustava, moralo stoga ostati nedovoljno analitički precizno i prepoznatljivo.

Iz takvog poimanja vrijednosti slijedi najoriginalniji Strpićev teorijski uvid u kritičkom čitanju Marxove "Kritike". Riječ je o već naznačenoj kategoriji “roba općenito". Ako je vrijednost doista samo "prividno neposredno određenje robe" (kakvom se mora činiti u izolirano prikazanoj početnoj apstraktnoj sferi jednostavnog prometa), ako "tek roba čija je vrijednost proizašla iz oscilacija cijena na konkurentskom tržištu ima vrijednost", ako cijeli teorijski sustav mora povratno djelovati na robu kao svoje ishodište i tako ga kružno konstituirati da bi sam mogao biti konstituiran - tada se iz takve stroge rekonstrukcije mora zaključiti da se u prvom poglavlju Kapitala I "o robi uopće ne radi"! Naime nije riječ o "običnoj”, pojedinačnoj robi, kako je Marx tvrdio još 1859. u Prilogu kritici političke ekonomije; a ne može biti riječ ni o robi "teorijski konkretiziranoj, o kakvoj bi moglo biti riječi tek da je Marx svoj teorijski plan izvršio u cjelini". Može se raditi samo o "robi općenito", o robi kao takvoj. Tek kao takva reflektirana kategorija "roba može postati, istodobno, i subjektom izvođenja kapitala, kao što je, uistinu, subjekt robnog formiranja društva u njegovoj suvremenoj ekonomskoj formaciji” (v. ibid.: 267, 271, 384-385).

Iz zakona vrijednosti kao "normale" preko koje se objašnjava konkurencijska logika cjenovnih oscilacija (v. ibid.: 191-192, 273, 335, 387, 394) Strpić će izvesti svoje dalekosežno poimanje "moderne normale" kao kontekstualne teorijske osnove političke analize socijetalnih ciklusa i kriza u Matrix-kapitalizmu. Poopćavanjem marksovske teorije vrijednosti Strpić gotovo oporučno nudi prvorazredan spoznajni izazov za buduća politologijska teorijska i empirijska istraživanja. Nudi složen teorijski sklop za analitičko istraživanje kako se "ravnoteža dinamičke strukture modernoga političkog prostora" (moderna normala kao ravnoteža između 1. političkoga, 2. individualnoga, 3. cjeline svjetskog prostora, 4. prostora države/ društva) višestruko narušava totalitarnom denormalizacijom (napose ulogom kapitalističke mega-korporacijske jezgre) (v. Strpić, 2009, 2010a, 2010b).

Strpićevo bravurozno tumačenje vrijednosti u kategorijalnom polju marksovske analize ne može se precijeniti. Može se valjano prosuditi tek pomnom analitičkom usporedbom s ranijim (kao što su Rubin, 1978/1928; Duménil, 1978; Backhaus, 1976/1969; Hribar, 1983) i novijim vrsnim tumačenjima i kritikama kategorije vrijednosti (Kurz, 2019; Postone, 2009/1993).

Napose bi teorijski bilo iznimno produktivno Strpićevu rekonstrukciju temeljnih Marxovih pojmova, vrijednosti i robe, sustavno sučeliti s radikalnom "kritikom vrijednosti”, prvenstveno u djelu Roberta Kurza (2002a, 2011, 2019). ${ }^{3}$

${ }^{3} \mathrm{Na}$ takvo je sučeljavanje već mjerodavno u nas upozorio Matko Meštrović (2018: 141-165). Premda Strpićevu rekonstrukciju Marxove "Kritike” znalački prikazuje i visoko vrednuje kao 
3. Po Strpićevu sudu, neprimjereno je Kapitalu pristupiti statički, kao čistoj sinkronijskoj konstrukciji. Valja mu pristupiti iz dinamičke perspektive teorije socijetalnih ciklusa i cikličkoga razvoja. Iz tendencijskih zakona povijesnog razvoja kapitalističke akumulacije valja razumjeti strukturu kapitala kao društvenog procesa proizvodnje, prometa i reprodukcije. Otuda epistemologijski primat kategorije dinamičke promjene u odnosu spram kategorija statičkog poretka i strukture.

Samo što se upravo u tome pojavljuje jedan od velikih problema u razumijevanju kapitalskog načina proizvodnje, kako nam je predstavljen u Marxovu Kapitalu.

Naime u prvom tomu Kapitala veoma su retorički efektno sažete povijesne tendencije kapitalističke akumulacije u dijalektičkim figurama "negacije" i "negacije negacije" (famozno koketiranje s Hegelom). Razvojna shema je izložena u 7. točki 24. pogl. "Historijska tendencija kapitalističke akumulacije" (Marx, 1974: 671-673). Prema toj shemi, dok je kapitalističko privatno vlasništvo negacija privatnog vlasništva zasnovanog na radu (odvajanje vlasništva od rada), dotle je novo društveno vlasništvo negacija negacije kapitalističkoga privatnog vlasništva, novi povijesni spoj rada i prisvajanja. Shema je efektna, ali neobrazložena, naprosto se ideologijski optimistički postulira: "Kuca posljednji čas kapitalističke privatne svojine. Eksproprijatori bivaju eksproprirani [...] nužnošću prirodnog procesa kapitalistička proizvodnja rađa svoju vlastitu negaciju”; i dalje, dok se u prvobitnoj akumulaciji kapitala radilo o "eksproprijaciji narodne mase od strane malog broja uzurpatora, ovdje se radi o eksproprijaciji malog broja uzurpatora od strane narodne mase". A kao potporu takvim proročkim najavama nalazimo citat iz političko-propagandnoga Komunističkog manifesta (prema kojemu "propast buržoazije i pobjeda proletarijata podjednako su neizbježni”)! Takvo je shvaćanje posve determinističko, u neodrživoj metafizici napretka kao nužnom zakonu povijesti, gdje je kritički znanstveni diskurs ustupio mjesto klasnoj ideologijskoj retorici. Riječ je o

“majstorsku interpretativnu i argumentativnu izvedbu" (ibid.: 143), Meštroviću se zaključno ipak čini da nam je autor ostao dužan, jer da se nije upustio u propitivanje "što se pak sa samom vrijednošću zbiva, i kao teorijskom kategorijom i kao zbiljskom povijesnom determinantom društvenog vremena i društvenih odnosa" (ibid.: 148). Upravo takvo propitivanje nudi novo kritičko čitanje Marxa, znano kao "kritika vrijednosti" (Wertkritik) i "kritika razdvajajuće vrijednosti” (Wert-abspaltungkritik), upozorava s pravom Meštrović (ibid.: 149-158). Takvu kritiku već desetljećima provodi snažna intelektualna grupacija okupljena najprije oko časopisa Krisis, a zatim Exit! (od 2004), u kojima je spiritus rector bio Robert Kurz (1943-2012). Već i sam podnaslov časopisa Krisis "prilog kritici robnog društva" upućuje na radikalnost pristupa kojim se kritički osporavaju svi temeljni pojmovi moderne (vrijednost, roba, novac, rad, država, demokracija, politika, subjekt) i naznačuju mogući obzori post-robno-novčano-radne civilizacije. U toj grupaciji ozbiljnu pozornost zaslužuju barem i Scholz (2001), Jappe (2003), Lohoff/Trenkle (2012), Ollman (2005), Artous (2006), kao i njima blizak autor Postone (2009/1993). Usp. veoma oštar i precizno obrazložen Bidetov kritički prikaz Postoneove interpretacije Marxa (Bidet, 2016c). 
lošoj dijalektici, njezinim se figurama ne može izraziti proboj iz danog totaliteta kapitalskoga načina proizvodnje života. Tzv. negacija negacije ne transcendira naime kapital kao totalitet građanske zajednice, nego samo mijenja njegove pojavne oblike. $^{4}$

Umjesto gordoga klasnog usklika “kuca posljednji čas!”, logika prijelaza iz kapitalističkog načina proizvodnje, kao robno-novčane proizvodnje viška vrijednosti, u "neki viši društveni oblik čiji je osnovni princip puno i slobodno razvijanje svake individue" (Marx 1974: 522) može se dokučiti tek ne-dijalektički kao kvalitativni prekid s postojećim epohalnim kapitalskim sklopom.

I sam je leksik dvojben i izvan je pojmovnog polja znanstvene analize. Najčešće, u Kapitalu se o kapitalistima govori kao o fanaticima oplodnje vrijednosti, a ne kao o "uzurpatorima", niti se o radnicima govori kao o "narodnoj masi". Premda je Marxu uvijek stalo do toga da istakne prolazni karakter kapitalističkog načina proizvodnje i kapitalista kao klase, ipak sasvim nedvosmisleno analitički upućuje na temeljnu funkciju kapitalista u procesu oplodnje vrijednosti: kapitalist je personifikacija kapitala, on je "samo funkcija kapitala, koji je u njemu došao do volje i svijesti”. A kada pak ukazuje na "dijalektički preokret" zakona robne proizvodnje i razmjene u kapitalističku metodu prisvajanja, onda precizira da je riječ o logičkom prijelazu u kojemu se ne krše, nego tek do kraja razvijaju zakoni robne proizvodnje i razmjene (usp. ibid.: 514-514, 518).

Usporedo s time postoji i neka vrst etičkog diskursa osude kapitalista kao klase eksploatatora, kradljivaca neplaćenog rada najamnih radnika. Odatle je samo korak do ideologijskog pravorijeka, do neopozive moralne osude kapitalista kao uzurpatora, koji narušavaju prirodno pravo radnika na vlasništvo nad plodovima svojeg rada. ${ }^{5}$

${ }^{4}$ Koliko lucidan toliko i uzaludan pokušaj spašavanja smislenosti teze o negaciji negacije dugujemo D. Bensaïdu. Premda priznaje da je riječ o "začudnom tekstu", koji formulacijski ("imanentni zakoni kapitalističke proizvodnje") svjedoči o objektivaciji i naturalizaciji povijesne "fatalnosti", on "formalizam negacije negacije" tumači ne kao "puku nespretnost", nego kao "neriješeno protuslovlje između utjecaja naturalističkog znanstvenog modela ("neizbježivosti prirodnog procesa') i dijalektičke logike otvorene povijesti” (1995b: 74-76; 1995a: 59-61). Premda sam zagovara diferenciranje kategorije vremena u čitanju Kapitala, Bensaïd začudo ne uviđa elementarnu stvar da se o historijskoj tendenciji kapitalističke akumulacije još uopće ne može ni govoriti u prvoj, nego tek u trećoj knjizi Kapitala!

5 Po sudu čuvenoga francuskog ekonomista i polihistora, Marxova "najdublja intencija" nije bila da svoju teoriju radne vrijednosti razvije zato da bi "objasnio relativne cijene ili se bavio makroekonomijom", nego ju je lokovski koncipirao kao "prirodnopravno pitanje vlasništva, legitimnog određenja raspodjele dobara. To je etička hipoteza o nelegitimnosti ropstva [...] Marksistička teorija kapitalističke eksploatacije očituje se kao specifikacija Lockeove teorije vlasništva zahvaljujući Ricardovoj teoriji cijena” (Kolm, 1986: 188-191). 
No i sama je teza o neminovnoj tendenciji podruštvljenja kapitala i nestanka lika kapitalista u njemu naprosto doslovno promašena, kapitalisti ne samo da ne nestaju nego se još i umnožavaju, kako nam sam Marx pokazuje kada u Kapitalu III objašnjava kako su dioničarska društva "direktno oblik društvenog kapitala (kapitala direktno udruženih pojedinaca) u suprotnosti prema privatnom kapitalu" (Marx, 1977b: 239).

Na Marxovo se koketiranje s kvaziuniverazalističkom dijalektikom povijesti u cijelosti može primijeniti Strpićevo upozorenje da se u Marxovim izričitim iskazima "često krije ne vlastiti Marxov znanstveni uvid, već njegov politički interes u celofanu znanstveno zapakirane proleterske ideologije" (Strpić, 2017: 384).

U trećem tomu Kapitala nalazimo pak znanstveno tumačenje tendencijskoga povijesnog zakona kapitalističke akumulacije izvedeno iz unutarnje dinamike totaliteta proizvodnje, prometa i reprodukcije društvenog kapitala (Kapital III, treći odjeljak: "Zakon tendencijskog padanja profitne stope", pogl. 13-15, str. 179-224; naročito pogl. 14: "Uzroci sa suprotnim djelovanjem”). Probojne točke samoprevladavanja kapitala ovdje su pojmljene uistinu dijalektički u punoj napetosti između oprečnih tendencija pada i sprečavanja pada prosječne profitne stope. Po mjerodavnome Strpićevu sudu, Marx

nije još dočekao da netko teorijski nadogradi na njegove famozne "uvjete sa suprotnim djelovanjem", iz trećeg toma Kapitala. Ta su "suprotna djelovanja", po mom sudu, temeljna za razumijevanje pa i izravnu izvedbu "konkurencije mnogih kapitala”, to jest teorije tržišta i cijena. No već za nju (što Marx, čini se, nije mislio) potreban je, po mom sudu, gigantski korak dalje, izvedba kritičke teorije države i politike... Konkretna tržišta su uvijek i politički konkretna, pa ih nije moguće razumijevati bez kritičke teorije države i društva te njihove regulacije. Kao ni bez svjetskog konteksta, koji je također uvijek i politički i društveni (i kulturni, i uopće komunikacijski), ne samo svjetsko-tržišni (2010b: 64-65; istaknuo D. L.).

U tom duhu Strpić će teorijski inovativno zagovarati razvijanje političke teorije socijetalnih (državno-društvenih) ciklusa. Suprotstavljajući se svjetskoj marginalizaciji političke znanosti i društvenih znanosti u cjelini, Strpić pokazuje kako upravo politologija ima izrazite strukturalne prednosti za uspješno istraživanje ne samo političkih nego i egzistencijalnih društvenih problema. To se nepovoljno stanje može i mora početi mijenjati u vrijeme izbijanja svjetske krize (2008), ali "samo ako se promijene uvriježene istraživačke strategije politologa. Orijentacija na rješavanje problema, osobito najvećih, ponajviše će unaprijediti javne politike kao politike razvoja, ali samo ako cijela politička znanost postane integriranom, bolje utemeljenom, dinamički i razvojno orijentiranom te bolje umreženom u širi sustav znanosti” (2008b: 211; 2010b: 145-182). 
Puni smisao Strpićeva dalekosežnog zagovora razvojne politologije kao politike razvoja upućuje političku znanost na otvaranje spram bitnih uvida napose filozofije u razumijevanju temeljnih kategorija naše epohe.

Primjerice, za razumijevanje krucijalne temporalne dimenzije Marxove kritičke analize kapitala kao društvenog procesa nezaobilazni su spoznajni doprinosi francuskog filozofa Daniela Bensaïda (1995a: 15-84; 1995b: 267-320) i njegova nekadašnjeg učenika, ciparskog filozofa Stavrosa Tombazosa (1994) koji analitički diferenciraju pojam temporalnosti u Marxovu Kapitalu. Sažeto: kategorije prve knjige upisuju se u logiku "linearne i apstraktne temporalnosti" proizvodnje, kategorije druge knjige u logiku ciklične (prometa), a kategorije treće u logiku organske temporalnosti (reprodukcije), kao jedinstva prvih dviju temporalnosti. ${ }^{6}$ Vrijednost (kapital) složena je pojmovna cjelina, protuslovan, procesualan i dinamički totalitet. Kapitalističke krize, kao "aritmije" društvenog organizma, nisu rezultat izvansistemskih čimbenika, nego su inherentni moment ekonomije ne-ravnoteže. Tako pojmljen kapital omogućuje konzistentnu interpretaciju moderne ekonomije, izvan neprimjerene logike identiteta, statike i ravnoteže.

\section{Marksovski i marksistički pristup}

Strpić je dosljedno i uvjerljivo inzistirao na temeljnom razlikovanju marksovskoga od marksističkog pristupa kritičkom razumijevanju i revolucionarnom osporavanju kapitalskog načina proizvodnje života. Neumorno je ponavljao i tumačio da je marksovsku znanstvenu kritiku političke ekonomije nužno razlikovati od ideologijske proleterske ekonomije rada. ${ }^{7}$ Povijesni marksizam pretežno je bio u tom smislu ideologijski-klasno obilježen, ne samo na području marksističke političke ekonomije. To je neminovno vodilo do regresije marksizma u sociologizam i historizam (što se ponekad nemarksovski nadoknađivalo refilozofikacijom).

No i Marx je sam prečesto zamagljivao to razlikovanje i s razine kritike građanskoga epohalnog sklopa (sa stajališta totaliteta, kako bi rekao Lukács) reduktivno se smještao na posebno klasno stajalište "proleterske političke ekonomije rada" ili "proleterske političke ekonomije radničke klase" - nasuprot "političkoj ekonomiji kapitala" ili "političkoj ekonomiji vlasništva". Povremeno iz njega "vikne pro-

${ }^{6}$ Bensaïd sažima svoje poimanje kapitala kao pojmovne organizacije društvenog vremena: "Tako se mehaničko vrijeme proizvodnje, kemijsko vrijeme prometa, organsko vrijeme reprodukcije omotavaju i uzglobljuju u krug krugova, sve do određenja zagonetnih pobuda povijesnog vremena, koje je vrijeme politike" (1995b: 95; v. cijeli prvi dio o Marxovoj kritici povijesnog uma, str. 19-114; napose poglavlje "Novo osluškivanje vremena", str. 85-114).

7 Uzoran je primjer: Thomas Hodgskin, Obrana rada protiv pretenzija kapitala (1825). To je odlučujuće razlikovanje temeljito obrazložio Jean-Pierre Osier u knjizi Thomas Hodgskin. Proleterska kritika političke ekonomije (1976). 
leterski politički ekonomist”. Tako u Grundrissima čak izjednačuje kapital kao takav i klasu kapitalista (Strpić, 2017: 387).

Po Strpićevu sudu, Marx je u svojim najboljim znanstvenim i kritičkim nastojanjima svoju kritiku osviješteno razlikovao od neposredne proleterske kritike, koja iskazuje stajalište samo "proletarijata ili radničke klase", jedne od klasa građanskog društva kao povijesne epohalne cjeline. Štoviše, na vrhuncu realizacije njegova teorijskog projekta " "proletarijat' i netragom nestaje iz Kapitala" (ibid.: 276; istaknuo - D. L.)! ${ }^{8}$

Marx se dakle kritički suočava s čak tri oblika političke ekonomije. Ponajprije, s klasičnom znanstvenom građanskom političkom ekonomijom (Smith, Ricardo), ali i s dvije suprotstavljene ideologizirane političke ekonomije: vulgarnom buržoaskom političkom ekonomijom (klasno stajalište s pozicije kapitala protiv rada) i proleterskom političkom ekonomijom (klasno stajalište prema kojemu "kapital nije ništa, već pljačka radnika, rad je sve", a koju ipak izbjegava nazivati vulgarnom).

Marx podvrgava kritici sva tri oblika političke ekonomije zato jer i građanska i buržoaska i proleterska politička ekonomija ovjekovječuju logiku kapitala kao društvenog procesa, kao načelno nenadmašivog epohalnog sklopa.

Zasluga je klasične građanske političke ekonomije što je uzorno znala pojavne kategorije konkurencije, tržišta i cijena svesti na temeljnu znanstvenu osnovu teorije vrijednosti, ali je bitan njezin nedostatak u tome što nije bila u stanju iz toga temelja valjano izvesti, uz nužne međučlanove, razvijene kategorije kapitalske robne proizvodnje.

Klasična (građanska, znanstvena, kritička, kapitalska) politička ekonomija, tumači Strpić, svodi razne oblike na njihovo unutrašnje jedinstvo, ali "to čini na način nedovoljno primjeren totalitetu reprodukcije kapitala kao niza dijalektičkih posredovanja rada robom. Kao što i na kapitalu neodgovarajući, izravan način pokušava iz rada izvesti sve svoje kategorije" (ibid.: 278).

Pritom je Marxova kritika nedovoljno diferencirana i pogađa u punoj mjeri prije svih Ricarda kao paradigmatskoga klasičnoga znanstvenog polit-ekonomista, kojega je čak uzdigao na "historijsko sistematsko mjesto analogno ili čak identično onome Hegelovom u povijesti filozofije" (ibid.: 277).

${ }^{8}$ Dakako, ne može biti tako. Osim posve formalno, tako da umjesto o proleterima i proletarijatu (kao u političkim spisima) Marx radije govori o radnicima ili najamnim radnicima te radničkoj klasi ili klasi najamnog rada (u znanstvenim spisima). Kada bi se moglo smatrati upitnim je li kapitalistički odnos kao "klasni odnos između kapitaliste i najamnog radnika" (Marx, 1977a: 34) jedan od glavnih problemskih sklopova Kapitala, tada bismo morali dovesti u pitanje i intenciju i smisao i samu izvedbu Marxove "Kritike". Pri čemu nije sporno da i u znanstvenim spisima Marx nerijetko koristi tipični proleterski klasni diskurs, kao kada, da navedem samo jednu ilustraciju, piše o "neizbježnom osvajanju političke vlasti od strane radničke klase" (Marx, 1974: 432). 
Marxova kritika, “dakako, ne vrijedi za Smitha, koji je metodološki i metodički sljedbenik Hobbesa i Humea; Marx mu to vidi, istodobno, i kao vrlinu i (pretežno) kao manu" (ibid.: 397, fsn. 310).

Vulgarne pak verzije političke ekonomije kreću se u fetišističkim kategorijama pojavnog svijeta tržišta i konkurencije (ideologijske kategorije kao istinita svijest lažnog bitka) (v. ibid.: 277-279; 2010b: 91-107; 1984: 179-190).

Marxovo odbacivanje obiju klasno uvjetovanih varijanti vulgarne političke ekonomije kao neznanstvenih nije posve opravdano i u cijelosti važi isključivo za proletersku političku ekonomiju (nadasve za Proudhona). "Buržoaska ekonomija" je "ipak sistematski bliska cjelini građanskog društva" i "načelno joj nije moguće sasvim ili uopće odricati znanstveni karakter", kako Marx “voli činiti” (2017: 397, fsn. 312).

$\mathrm{Na}$ tom tragu, suvremena je diskusija zaoštrena do razotkrivanja bitne Marxove dvostrukosti. U čuvenom i veoma utjecajnom tekstu "Dvostruki Marx" (prvi put objavljenom u sklopu obilježavanja 150. obljetnice Komunističkog manifesta, 1998) Robert Kurz uvodi razlikovanje između "egzoteričnog” i "ezoterijskog" Marxa. Marxovu teoriju karakterizira veliko unutarnje protuslovlje između prvoga "egzoteričnoga", javnosti jedino znanog i svjetski utjecajnog "analitičara politike i mentora radničkog pokreta", s jedne strane, i drugoga "ezoterijskoga" još uvijek nedovoljno poznatog teoretičara robnog fetišizma modernog društva i kritičara "društvenog oblika vrijednosti sāme" koji "tvori strukturu bez subjekta", s druge.

Prvi je Marx autor manifesta o "klasnoj borbi" koja je odredila "evoluciju modernog svijeta između 1848. i 1989”. S današnjeg stajališta pokazuje se da ta povijesna borba nije dovela do kraha kapitalističkog sustava, nego da je bila "interni pogon njegova razvoja”. Rezultati nisu za podcjenjivanje (povišenje nadnica, skraćenje radnog vremena, sloboda udruživanja, opće pravo glasa, državni intervencionizam u ekonomiji, industrijska politika...), ali još se kreću unutar fetišističkoga robnog i novčanog svijeta.

Taj je projekt ispunio svoju punu mjeru, s njime završava jedna epoha, Komunistički manifest izgubio je svoju motivacijsku snagu jer više ne odgovara na temeljna pitanja našeg doba. Otuda kuca čas za pojavljivanje "ezoterijskog” Marxa kao kritičara fetističkoga robnog svijeta. Urgentna je zadaća "napisati novi manifest, za koji još nije pronađen jezik" (Kurz, 2010).

Samo godinu dana kasnije jezik je "pronađen", Kurz je s najbližim suradnicima (Lohoff i Trenkle) u njemačkome časopisu Krisis objelodanio spektakularni pamflet Manifest protiv rada u kojemu se u marksističkoj borbenoj maniri obznanjuje konačni "kraj radnog društva". Započinje retoričkom figurom slavnog preteče: "Lješina vlada društvom, lješina rada. Sve sile svijeta ujedinile su se da bi obranile tu dominaciju: papa i Svjetska banka, Tony Blair i Jörg Heider, sindikati i 
poslodavci/ke, ekologisti Njemačke i socijalisti Francuske. Svi/sve imaju imaju samo jednu riječ u ustima: rad, rad, rad!"

Manifest objašnjava da su kapital i rad dva lica iste medalje, da tradicionalna ljevica i njezina teorija oduvijek sakraliziraju i mitiziraju vrijednost rada, zagovarajući ropsko oslobođenje rada umjesto emancipacijskog oslobođenja od rada. Rad međutim nije nikakvo oslobođenje, ni empirijski ni teorijski, društvo rada suprotno je slobodi. Rad je osnova demokracije kao "najperverznijeg sustava u povijesti: to je sustav samo-tlačenja". S kritičkom poantom: "Obnova radikalne kritike kapitalizma pretpostavlja kategorijalni prijelom s radom". Samo utvrđivanje novih obzora emancipacije "onkraj rada i njegovih fetišističkih kategorija" može stvoriti novi "javni protu-prostor" i sporazum protiv rada kao osnovicu "društvenog pokreta protiv rada" (Krisis, 2002: 3, 8, 13, 19, 20).

Iz takvoga manihejskog programa koji proročki neopozivo obznanjuje "kucnuo je čas konačne smrti rada", pozornost zaslužuje osnovna promišljena argumentacija da je novovjekovni robno-kapitalski svijet i njegov model modernizacije konačno ispunio svoju punu povijesnu mjeru, da bitno pripada prošlosti. Kurz je tu osnovnu argumentaciju izložio napose u svojim veoma utjecajnim knjigama Kolaps modernizacije (1991) i Crna knjiga kapitalizma (1999).

\section{Smisao povratka od Marxa k Hobbesu, rodnome mjestu novovjeke političke znanosti}

Fundamentalno djelo francuskog filozofa Jacquesa Bideta Opća teorija moderne (2008/1999) Strpić je popratio pogovorom "Marx koji nedostaje”. U retrospektivnom osvrtu na važnost Marxove kritike političke ekonomije kao "skoro nadljudskog” pothvata i na svoja temeljna istraživanja toga epohalnog projekta Strpić objašnjava da nam ne nedostaje samo Marx (uzgred, i Ricardo), nego i "za početak neki novi Hobbes", jer bez njih "praktički nije moguće izvesti uspješnu teoriju suvremenog dovršavanja Moderne i prospektivnog izlaska iz nje" (Strpić, 2008a: 366367, 380, 381-382; 2010b: 15, 32, 34-35).

Zašto nam, za početak, nema budućnosti bez "novoga" Hobbesa? Zašto baš bez njega?

Izričit i obrazložen odgovor naći ćemo u glavnim radovima Daga Strpića (2017/1991: 25-36, 52-57, 109-117, 119-122, 148-155, 284, 339-342, 356-364; 1998: 7-10; 2015: 17-28) u kojima je dosljedno dokazivao utemeljujuće značenje Hobbesove političke teorije za razumijevanje cjelokupne klasične britanske političke teorije (Locke, Hume, Ferguson, J. S. Mill) i političke ekonomije (J. Mill, Petty, Smith, Ricardo, Steuart).

Ali ne samo to! Politolog Dag Strpić samosvjesno se čak izjašnjava kao hobsist. Nije ustuknuo ni pred iskazom kako "hobsist nolens volens mora biti svatko 
tko je ozbiljno zaokupljen istraživanjem novovjeke političke znanosti i filozofije društva" (Strpić, 1998: 7). Tim nadasve spoznajno izazovnim, a među teorijski neuznemirenim politolozima i jedva razumljivim postulatom započinje Strpićeva knjiga Promjena, s rječitim podnaslovom Politička i političko-ekonomska promjena od Hobbesa do Hayeka (1998).

U ovoj bih se prilici ograničio samo na jednu metodički važnu Strpićevu tezu o dvojstvu u samom izvorištu modernoga političkog mišljenja, koje uobičajeno utjelovljuju imena Machiavellija i Hobbesa. Po njegovu nadasve intrigantnom sudu, dok je Hobbes utemeljitelj politologije (mišljenje Commonwealtha kao moderne radno-razmjenske zajednice), dotle je Machiavelli začetnik politikologije (kao analize politike i političke vlasti).

Polazeći od toga da je politologija teorija zajednice, Strpić općenito ustvrđuje: "U klasično doba, s početka novog vijeka, svojevrsni obrat na svjetovnu osnovu izveli su u politologiji, kao teoriji zajednice, Thomas Hobbes, Niccolò Machiavelli i teoretičari prirodnog prava" (2017: 25).

Da bi zatim iznio i slijedeći sud: "Machiavelli ide dalje od toga i pokazuje politiku, kao odnošenje spram vlasti i borbu za nju, kao specifičnu novovjeku karakteristiku zajednice. Otuda on utemeljuje usmjerenje političke teorije kao politikologije, koje je dominantno u XX. stoljeću, kada ova znanost dolazi svome vrhuncu" (ibid.).

S poantom: "Za nas je, međutim, interesantniji - a i objektivno je važniji onaj smjer razvoja političke teorije koji je utemeljen po Th. Hobbesu”. Zašto? Prvenstveno zato što je Hobbes uvidio "novi značaj politike u građanskoj zajednici - državi/društvu [Civil society, Common-wealth]”, što svoju novu političku teoriju "sistematski temelji novim shvaćanjem centralnog mjesta sile/moći [Power] u prirodi i društvu..." (ibid.).

Hobbes je dakle utemeljitelj moderne politologije kao sistematske znanosti građanske zajednice (ibid.: 26).

Strpić je naime uvjeren kako je Hobbesova znanost o politici rodno mjesto poimanja logike konstitucije i reprodukcije Common-Wealtha kao moderne građanske zajednice (političko-ekonomske). Temeljna je "odlika moderne produkcije zajednice kao državne zajednice" razmjena moći, odnosno podvrgavanje "rada (kao osnovne prirodne moći čovjeka) pod razmjenski odnos (kao temeljni društveni odnos građanskog društva)". A sam je razmjenski odnos moguć tek pod pretpostavkom "privatnoga vlasništva i njegovih tržišno-ugovornih transfera", s jedne strane, i "moći zajednice, zajedničke/opće moći [Common-power], konstituirane u apsolutnu, suverenu vlast", s druge. Zajednica je stoga procesualno određena kao razmjensko istodobno "razlaganje" (partikularizacija) i "rekomponiranje" (poopćavanje) tokova i mreža moći, a ne kao stabilan i nepromjenjiv poredak. 
Suočeni smo s dobro znanim problemom, koji se danas postavlja kao odnos "makijavelijevskoga" (Pocock) i "hobsovskoga" (Lalović, Ribarević) logičkog momenta u strukturi modernoga političkog mišljenja - s dvojbom koji je teorijski moment logički prvi i utemeljujući za modernu zajednicu, a time i za politologiju (prisjetimo se čuvenoga Straussova kolebanja oko toga počinje li moderno mišljenje s Hobbesom, kako je dugo mislio, ili ipak s Machiavellijem, kako je na kraju zaključio).

Novovjeko političko mišljenje doista karakterizira načelna napetost između makijavelijevskoga republikanskog momenta političkoga (političkoga u njegovoj emancipacijskoj dimenziji) i hobsovskog antirepublikanskog momenta države (svođenjem političkoga na politiku u njezinoj regulacijskoj dimenziji).

Mogu se ovdje tek uzgredno osvrnuti na takvo ovlašno pozicioniranje Machiavellija u kontrastu spram Hobbesa. Svođenje makijavelijevskoga političkog nauka na pitanje osvajanja i održavanja političke vlasti, koliko god ga empiricistička politička znanost svodila na tu višestoljetnu predrasudu, odavno nije održivo. Pogotovo nakon fundamentalne interpretacije Claudea Leforta Rad djela. Machiavelli (1972) kao glavnoga referentnog okvira za suvremeno čitanje političkog opusa velikog Firentinca. Za Leforta je Machiavelli teoretičar političkoga koji otkriva novu protuaristotelovsku ontologiju političkog bitka koja se temelji na društvotvornoj vitalnosti klasnog sukoba, pri čemu se političko nipošto ne može svesti na instrumentalnu politiku gospodarenja fortunom, niti na tehniku stjecanja i očuvanja vlasti. Machiavellijevo poimanje političkoga rodno je mjesto modernoga mišljenja u kojemu politička teorija postaje prima philosophia. ${ }^{9}$

${ }^{9}$ Za cjelovito kritičko vrednovanje Lefortova virtuoznoga hermeneutičkog čitanja Vladara i Rasprava upućujem na impozantnu studiju politologa Davorina Žagara (2019). Slijedeći Leforta, u kontrapunktu spram Straussa, Žagar pomno obrazlaže kako je Machiavellijev politički nauk u Vladaru i Raspravama inovativni teorijski uvjet mogućnosti političkog djelovanja koje se temelji na slobodarskim političkim težnjama puka kao klase. Firentinac poima klasni konflikt između velikaša (patricija) i pučana (plebejaca) kao središte svakoga Grada, kao izvor njegove životnosti, zakona i slobode. Klasni sukob je predstavljen kao univerzalna karakteristika političkih društava, antičkih i modernih, u svakome postoje dvije klase koje su određene samo kroz međusobni odnos dviju antagonističkih i podjednako neutaživih političkih težnji (umori): dok velikaši teže tlačenju i gospodarenju pukom, puk se tome suprotstavlja. Njihove su težnje suštinski različite: dok velikaši teže imati/stjecati, puk želi biti/živjeti. Sama priroda klasnog sukoba upućuje na to da je taj sukob nerazrješiv. Političko tijelo se nikada ne može u potpunosti svesti na jedinstvo. Lefort Machiavelliju pripisuje otkriće izvorne društvene podjele, a time i izumljivanje nove ontologije političkoga bitka. Machiavelli se bavi istraživanjem mogućnosti konstituiranja trajnog i moćnog poretka koji je utemeljen na nerazrješivoj podjeli i punom priznanju klasnih težnji. Politički poredak koji teži postići trajnost i maksimalnu snagu mora zadobiti podršku puka. Machiavellijevi nuovi modi e ordini označuju državu utemeljenu na težnji puka. Puk kao klasa je istinski čuvar slobode poretka i izvor je njegove snage. U tom smislu Machiavellijev je nauk svojevrsna rana teorija demokracije (v. Žagar, 2019: 157-305). 
Posve sam suglasan sa Strpićem u pogledu epohalne važnosti scientiae civilis T. Hobbesa: Levijatan je nezaobilazno utemeljujuće djelo modernoga političkog mišljenja. I sam se njime bavim desetljećima s neuzrdmanim uvjerenjem da "za političke znanstvenike nema drugog puta - svi putovi vode preko Hobbesa. Od njega, prema njemu, protiv njega" (v. Lalović, 2006b: 131).

Uza svu suglasnost o Hobbesovoj važnosti, interpretativne razlike među nama bile su znatne, kao što sam pokazivao u brojnim radovima (v. Lalović, 2006a, 2006b, 2008b, 2009, 2015, 2017b). No ovdje bih se ograničio i fokusirao samo na Strpićevo tumačenje Hobbesova poimanja politologije u razlici spram politikologije.

Što je pritom osnovni problem? Problem je u određenju karaktera moderne građanske zajednice i karaktera individua koje ju konstituiraju. Čisto terminologijski, Common-Wealth Strpić najčešće izražava složenicom "država/društvo" ili "državna zajednica" (2017: 363); ali često nailazimo i na "građansku zajednicu", a nerijetko i "društvo ili građansko društvo"; ${ }^{10}$ u posljednjoj fazi odlučuje se za termin "država-nacija" ili "veliko građansko društvo" (v. "Država-nacija kao političko-ekonomska zajednica", 2015: 17-28). Tko pak konstituira takvu zajednicu, koji lik modernog čovjeka, tko su subjekti konstitutivnog pactuma societatis? Strpić smatra da su to individue općenito, odnosno ekonomski građani (ili bourgeois) do kojih moramo dospjeti ako društvo analitički razložimo ("rezolutivno") na njegove sastavne dijelove. A ako od tako pojmljenih pojedinaca, članova građanskog društva, ponovno logički složimo ("kompozitivno") društveno tijelo, dobit ćemo Common-Wealth i spoznati ga kao političko-ekonomsku zajednicu ugovorno udruženih pojedinaca.

Strpić pritom primjereno uočava da su momenti zajedničkosti (kao opće moći) i individualnosti (kao osobne moći) konstitutivno međuuvjetovani u složenoj mreži tokova i razmjena moći. "Društvo i pojedinci od kojih je ono sastavljeno izgledaju kao dvije jedine 'date' ove operacije [rezolutivno-kompozitivne]. Jedna se pretapa u drugu i jedna se dokazuje kao istinita, odnosno nužna - uvijek onom drugom” (Strpić, 2017: 28; istaknuo - D. L.).

U takvom razumijevanju Hobbesove političke teorije u kategorijama moći (power) Strpić se oslanja na Macphersona $(1968,1981 / 1962),{ }^{11}$ a potvrdu može naći i u veoma utjecajnoj interpretaciji Lea Straussa (1971/1953), koji ne samo Hob-

${ }^{10}$ Usp. napose Strpić, 2017: 109-117. Štoviše, već u samom naslovu šestog poglavlja nalazimo "Common Wealth kao razmjenska zajednica", a u točki 1 tog poglavlja čak i "Common-wealth kao robna zajednica” (ibid.: 109).

11 Vidi u ovom broju pomno argumentiranu superiornu kritičku valorizaciju Strpićeve kritičke recepcije Macphersonova čitanja Hobbesa u izvrsnoj studiji Luke Ribarevića "Politička ekonomija u Levijatanu: Hobbes, Macpherson i Strpić". 
besov politički nauk nego i njegovu cjelokupnu filozofiju tumači kao prvu filozofiju moći (philosophy of power). ${ }^{12}$

Takvo je tumačenje Hobbesa neopozivo doveo u pitanje Yves Charles Zarka u ključnoj knjizi suvremene sekundarne studijske literature o Hobbesovu teorijskom sustavu. Njegova knjiga Metafizička odluka. Uvjeti politike (1999/1987) strogo hermeneutički dokazuje da je Hobbesova etičko-političko-pravna filozofija semiologija vlasti, a ne sociologija vlasti (pouvoir). ${ }^{13}$ Hobbesov "prirodni čovjek" primarno je biće jezika, a ne biće moći, moć je njegovo sekundarno određenje. Hobbes nastoji pokazati kako je moguće da se "prirodni" čovjek od bića moći preobrazuje u biće prava ili kako se zgoljna potentia (moć) preobrazuje u pravnu potestas (vlast). Logika moći nije logika uzajamnosti, nego logika rata, pa je otuda ključno pitanje: kako je iz ratnog stanja sukoba (na temelju ius in omnia) svakoga sa svakim moguć prijelaz u građansko stanje pravnog mira i međusobnog priznanja? Samo se diskurzivno (ugovor pretpostavlja sposobnost govorenja i razumijevanja) "prostor sukoba transformira u prostor zajednice uzajamnoga pravnog priznanja, čime se prelazi s drugoga kao neprijatelja na drugoga kao biće prava" (Zarka, 1999: 292). I time utemeljuje Common-Wealth ili State (po izričitim Hobbesovim riječima). Takva se pravna transformacija u mediju jezika (ugovora) postiže tek u Levijatanu (1651) najzad uobličenom teorijom autorizacije ${ }^{14}$ (koje još nema u De cive, 1642), ugovornim izlazištem države kao građanske osobe i suverene vlasti kao predstavničke vlasti. Na suverena budući državljani sporazumom ne prenose moć (jer se moć i ne može transferirati), nego ga pravno ovlašćuju da bude njihov opunomoćeni zastupnik, pa da njegova suverena općenita politička volja bude volja svakoga pojedinačno i svih njih zajedno (Zarka, 1999: 293-356).

U Hobbesovu određenju statusa naturalis nalazimo dakle čovjeka u kvaziprirodnom stanju koje nije reducirano na logiku imanencije moći/vlasti i tržišta, ne-

12 V. Strauss, 1971: 169 (v. i 1965: 194). Strauss pritom upozorava: “"Moć' je dvosmislen termin. On s jedne strane označuje potentia i, s druge strane, potestas ili jus ili dominium)... Dvosmislenost je suštinska: jedino ako su potentia i potestas stvarno neodvojive može se ostvariti pravedan društveni poredak. Država kao takva istovremeno je i najveća ljudska sila [force] i najveći ljudski autoritet [authority]. Pravna moć/vlast [power] je izuzetno velika sila... potentia čovjeka jest ono što čovjek može da uradi, a potestas ili, općenitije rečeno, pravo čovjeka jest ono što čovjek smije da uradi" (ibid.).

13 Usp. “... je li uvjet jezika društvo ili je uvjet društva jezik? Upravo zato što Hobbes riječ i verbalnu komunikaciju čini uvjetom društva, a ne obrnuto, njegova je politička filozofija semiologija vlasti, a ne sociologija vlasti" (Zarka, 1995: 97).

14 Danas se o Hobbesovoj scientii civilis ne može teorijski mjerodavno suditi bez uvažavanja Zarkina temeljnoga interpretativnog doprinosa (u nas, uzorno: Ribarević, 2016). Prethodi mnogo poznatijoj, Skinnerovoj interpretaciji Hobbesove političke teorije (1987. versus 1989/1997/2002), a teorijski je nedvojbeno nadmašuje. 
go u jeziku kao svojem bitku čuva mogućnost transcendencije individue kao autonomnog subjekta.

U punom osloncu na Zarku, Bidet u Hobbesovu nauku nalazi ishodište svoje opće teorije moderne: na početku moderne bijaše riječ, riječ hobsovskoga prirodnog čovjeka koji progovara jezikom društvenog sporazuma (teorija autorizacije). Načelo je konstitucije (moderne) države diskurzivno (Bidet, 1999: 16; 2008: 23). "Država kao umjetno pravno biće fundamentalno je povezana s jezikom" (Zarka, 1995: 20; istaknuo - D. L.)

Otuda se, u bitno drukčijem interpretativnom ključu, potvrđuje stajalište o primatu hobsovskog momenta u povijesti klasičnoga političkog mišljenja. Hobsovski se logički moment udvaja u moment diskursa i moment države. Diskurzivni moment konstitucije modernog čovjeka logički prethodi makijavelijevskome momentu političkoga. Takvo temeljno diferenciranje hobsovskog momenta nameće bitnu korekciju u razumijevanju politike i države uvažavanjem antropologijskog postulata o diskurzivnoj i simboličkoj dimenziji bivstvovanja modernog čovjeka (v. Lalović, 2017b).

Tek se u tom rekonstruiranom kategorijalnom polju Hobbesa može s pravom smatrati utemeljiteljem politologije kao teorije države, kao zajednice slobodnih državljana, odnosno pravnih i ekonomskih subjekata.

Kako u tom svjetlu vrednovati Strpićevo pozicioniranje Hobbesa kao političkoga teoretičara i polit-ekonomista? Je li ono u cijelosti upitno, napose s obzirom na sugeriranu mogućnost razlikovanja politikologije (nauka o politici) i politologije (nauka o radno-razmjenskoj zajednici)?

Označio bih Strpićevo čitanje Hobbesa i cijele klasične britanske političke teorije (pa zatim čak i Hegela) kao suštinski polit-ekonomsko. Takvo čitanje u jednoj dimenziji bitno obogaćuje naše shvaćanje Hobbesove "scientiae civilis", kada je tumači kroz na radnoj "prirodnoj” ili instrumentalnoj moći zasnovanu procesualnu logiku društvenog tijela, kao permanentno razlaganje totaliteta na osobnu moć/privatno vlasništvo i preslagivanje partikulariteta u opću moć radno-razmjenske zajednice. No takva zajednica, makar i kao Common-Wealth, još nije država kao javnopravna građanska osoba, personificirana u predstavničkom suverenu, nego je striktno rečeno društvena zajednica ili građansko društvo u kojemu je novac kao "opća moć” temelj proizvodnje zajednice (Strpić, 2017: 209). Ali građansko društvo kao sfera opstanka modernog čovjeka nije cjelina zajednice, nego je cjelina odnosa i institucija koji obuhvaćaju kompleksnu mrežu društvene opće moći novca/imovine i vlasničke moći privatnih ekonomskih građana. Pri čemu je rad/moć temelj konstitucije razmjenske zajednice.

Strpić, dakako, zna i ističe da je državna zajednica = Common-Wealth, preko osobe svog suverena, najviša moć/vlast, jer je u suverenu "personificirana Common 
Power, zajednička/opća moć svih u njoj udruženih ljudi" (ibid.: 284); na drugom je mjestu naziva i "općom/zajedničkom suverenom moći” preko koje se proizvodi i reproducira "državna zajednica" (ibid.: 229).

Međutim pritom se ispušta iz vida temeljno razlikovanje društvene moći novca kao zajednice i suverene vlasti kao javne političke, pravne i etičke instance. Do takve kategorijalne nivelacije društveno/privatne moći i državno/javne vlasti dolazi zbog neuvažavanja temeljnog postulata da lik individue koja sporazumom diskurzivno i pravno utemeljuje državu nije ekonomski građanin, nego prirodni čovjek kao moralni i politički subjekt.

Riječ je o jednoj od temeljnih teorijskih zamki s kojom nas suočava Hobbesov Levijatan, a na koju je s pravom upozorio francuski filozof Luc Foisneau kada govori o "cirkularnoj relaciji koja se uvodi između dvaju značenja pojma subjekta". Cirkularnost se očituje u tome što Levijatan "ide od subjekta [sujet] do podanika [sujet], odnosno od subjekta kojega definiraju njegova prirodna prava do podanika kojega definira njegova suštinska poslušnost" (Foisneau, 2016: 446). ${ }^{15}$

Drugim riječima, čovjek je u logički predgrađanskom stanju samo apstraktni moralni subjekt, koji tek posredstvom države konkretno može ozbiljiti, najprije, svoj pravni subjektivitet, a u perspektivi i svoju punu moralnu autonomiju. Upravo je to i najviše legitimiranje države kao političkog autoriteta ili "pravedne vlasti" (Hobbes kaže "just power"), koja je kolektivni instrument moralizacije svojih državljana pozitivnozakonskim jamčenjem valjanosti prirodnih ili moralnih ili božjih zakona. Suveren personificira državu samo u mjeri u kojoj je konkretno utjelovljenje javne savjesti, legitimni tumač prirodnih ili moralnih normi.

Kao što vidimo, polit-ekonomsko čitanje Hobbesa koje u prvi plan postavlja problem moći istodobno i obogaćuje i osiromašuje pojmovno polje Hobbesove znanosti o politici. Ono podcjenjuje ili previđa nekoliko već naznačenih dimenzija Hobbesova razumijevanja politike u povezanosti s pravom i moralom. Ako je naime power doista politička vlast, ona je to "samo utoliko ukoliko proizvodi znakove kodificirane pravom. U tom smislu potestas je istodobno i potentia i ius, dimenzija prava u cijelosti proistječe iz simboličke funkcije" (Zarka, 1995: 91).

Poteškoće Strpićeva tumačenja Hobbesova političkog nauka jarko ocrtava važna napomena našeg autora u kojoj upozorava kako Hobbesa ne valja čitati. Po Strpićevu sudu, "striktno pravno-politička analiza" Hobbesov nauk svodi na "politikološki circulus vitiosus" u kojemu su temeljni kategorijalni par "političko-pravna

15 Foisneau se pritom poziva na Foucaulta, koji je lucidno zamijetio da se problem očituje u tome "kako subjekt [sujet], shvaćen kao individua koja je prirodno (ili po prirodi) obdarena pravima, sposobnostima, itd. - može i mora postati podanik [sujet], ali ovog puta shvaćena kao podvrgnut element u odnosu moći/vlasti [pouvoir]" (v. Foucault, 1997: 37). 
država" i "političko-pravni pojedinac" (Strpić, 2017: 30). Njemu se čini da taj kategorijalni par vodi političku teoriju u reduciranu, na državu i vlast usredotočenu politikološku analizu, pa zaključuje: "svaka je takva politička teorija - građanska teorija" (ibid.).

Takva napomena a contrario objašnjava "Hobbesovu politologiju” (ibid.: 121) ili Hobbesovo "politološko istraživanje" (ibid.: 31). Strpić nam zapravo kaže dvije stvari. Prva, da je pravno-politička analiza, koja ne uvažava uvide polit-ekonomske znanosti, spoznajno defektna jer ne razumije anatomiju i fiziologiju građanske zajednice. No dok je takva napomena nesporna, to nije slučaj i s tezom kojom se osporava kategorijalni par političko-pravna država/političko-pravni pojedinac. Naime upravo taj par konstituira teorijsko polje političke znanosti i glavni je Hobbesov doprinos njezinu modernom konstituiranju. Najprije, totalitet je država kao epohalno nov tip političko-pravnog poretka impersonalne vlasti (Skinner, 1989/1997/2002; Lalović, 2008a), a ne građansko društvo ili društvo kao radno-razmjenska zajednica. Hobbesov Common-Wealth nije u strogom smislu političko-ekonomska zajednica - nego pravno-ekonomska - jer političkoga nema bez mogućnosti političkoga građanina (citoyen) da sudjeluje u obrazovanju javne političke volje.

Nadalje, član tog poretka je pravni subjekt i/ili politički građanin, a ne član građanskog društva ili ekonomski građanin. Ogromna je Hobbesova zasluga da je taj tip dvorazinske političke analize učinio temeljem moderne političke znanosti, pogotovo zato što je taj teorijski model mogao biti produktivno primijenjen na političku teoriju demokracije, kao kod Rousseaua (Lalović, 2006c, 2017b).

Kada bi dakle bilo točno da takav tip političke teorije nije politologijski, nego politikološki, tada bismo morali zaključiti da je i sam Hobbes - politikolog. Štoviše, da uopće i nema politologije!

Ako smo pažljivo slijedili Strpićevo tumačenje Hobbesova teorijskog modela, morao nam se nametnuti zaključak da je Hobbes zapravo prvenstveno društveni, a tek sekundarno politički znanstvenik. Takav se zaključak potvrđuje kada Strpić svoje istraživanje usredotoči na Adama Smitha, na Smithovu "klasičnu paradigmu", te ustvrđuje: "Smithova teorija... uzeta u cjelini njegova sistema, nije samo političkoekonomska već i politologijska, i to par excellence" (2017: 245; istaknuo - D. L.).

Ako se čak i Smitha može tumačiti kao politologa, a ne samo kao polit-ekonomskoga i društvenog znanstvenika (Strpić piše o Smithovoj "društvenoj teoriji”, ibid.: 63), ako je njegov tip analize čak eminentno politologijski, tada se gube jasni obrisi razlikovanja političke znanosti spram srodnih disciplina, napose spram sociologije politike i političke filozofije, koje se kao podređeni momenti podvode pod obuhvatno određenje politologije kao integralne znanosti.

Jednu od mogućnosti plodnog izlaska iz takvih nedoumica ponudio nam je valjda i najveći suvremeni politički filozof Leo Strauss tako što je u svojemu kanon- 
skom pregledu povijesti političke filozofije (u suradnji s Josephom Cropseyem) i Hobbesa i Smitha uvrstio među - političke filozofe. Pri čemu se pokroviteljski ljupko na samom početku knjige ističe da joj je "prvenstveno namjera... upoznati studente političke znanosti s političkom filozofijom" (Strauss/Cropsey, 2006: 7).

A nije li moguće da su upravo takve nedoumice teorijski produktivne, pod uvjetom da se u njih ne zatvorimo, nego da se prisjetimo, recimo, da je među velikim klasicima - i Spinoza?

Nema nikakve dvojbe da se važnost Hobbesove znanstvene paradigme i za suvremenu političku znanost ne može dovoljno istaknuti, ali uz sav respekt spram Strpićeve politologijske interpretacije koja na tome tako sugestivno inzistira, ipak se Hobbesa kao klasičnog mislioca ne može svesti na politologa. A i obrnuto, svesti politologiju na Hobbesa znači izgubiti iz vida da je sloboda, a ne moć, temeljni predmet proučavanja i raison d'être političke znanosti.

\section{Zaključno o Strpićevu nasljeđu u čitanju Marxa}

Uvodno je naznačen samosvjestan istraživački program još mladog marksista i politologa Daga Strpića, koji je obznanio kao neodložnu zadaću marksista da kategorijalni aparat "Kritike" dalje razviju Marxovim načinom, da marksovskim načinom započnu posao autentičnog dovršavanja Marxova nedovršenog djela. S plaidoyerom da "konačno počnemo čitati 'Kapital' onako kako ga je Marx pisao i kako ga je mislio. Uz nezaobilazno kritičko preispitivanje njegove literature i cijele tradicije iz koje ta literatura izlazi, kao i njegovog recipiranja te literature i te tradicije" (v. supra, Strpić, 1982).

Tada je Dag Strpić bio na prvoj polovici puta (1975-1982) u svojemu marksovskom (zapazimo: ne i marksističkom) nadasve ambicioznom i zahtjevnom istraživačkom projektu, koji je daleko nadmašivao i najstrože znanstvene kriterije za izradu doktorskih disertacija. Kada je apelirao da se "započne posao" i "konačno počne čitati 'Kapital'”, da se kritički preispita Marxova literatura i način na koji ju recipirao, on se u taj "posao" već uvelike bio upustio.

Kada pak ocjenjujemo konačne rezultate Strpićeva istraživačkog programa na temelju velike studije iz 1991, o kojoj je podrobno bilo riječi, ne možemo a da se završno ne zapitamo u kojoj je mjeri realiziran.

Još određenije: može li se iz te studije najzad bolje razumjeti zašto Marx nije dovršio svoju "Kritiku"? I još: je li Strpić uspio dovršiti ili započeo dovršavati ono što Marxu nije pošlo za rukom?

Slijedimo li pomno Strpićevu minucioznu interpretaciju Marxovih tekstova, od Ekonomsko-političkih rukopisa (1844) preko Njemačke ideologije (1846), Bijede filozofije (1847), Grundrissa (1857-1858) i Priloga kritici političke ekonomije 
(1859) do Kapitala I (1867/1872) (uključujući Kapital II-III i Teorije o višku vrijednosti I-III) - pred nama se uvjerljivo ocrtavaju sve poteškoće Marxova pokušaja da teorijski svlada i kritički prevlada tradiciju klasične građanske političke ekonomije.

Kao što smo vidjeli, ocjenjujući Marxovo čitanje te tradicije Strpić ne samo implicitno nego i izričito precizno upozorava na manjkavosti Marxove recepcije građanske političke ekonomije. Tako Marxovo početno bavljenje političkom ekonomijom (1843/1844) kritički prosuđuje kao "početničko, autsajdersko pogrešno razumijevanje" (2017: 169), zamjerajući mu da "još nije do kraja shvatio velikog majstora [Hegela], a nije shvatio ni njegovu ekonomsku literaturu, koju bi htio da na brzinu apsolvira" (ibid:: 170).

Čitajući britanske klasike, i s Marxom i mimo njega, Strpić je zaključio da se Marx u svojoj kritičkoj ambiciji prevladavanja Adama Smitha, ključnog teoretičara klasične političke ekonomije, naprosto samozavaravao da može ponuditi pravu "kritičku" izvedbu kategorije vrijednosti umjesto "Smithovih "pomiješanih metafora' u kojima se radi više o društvu nego o vrijednosti robe". Pokazuje se da "Smithovih određenja vrijednosti Marx se nije - kao ni mnogo čega drugoga - uopće, a ponajmanje kritički riješio". Stoga mu se dogodilo da je i ne znajući preuzeo upravo Smithov pristup "robi kao temeljnom (ili 'elementarnom') ekonomskom tijelu", kao vezivnom elementu društva, koji ga "stalno hjumovski izgrađuje i razgrađuje" (ibid.: 272-273). ${ }^{16}$

Time Strpićevo veliko istraživanje iznosi na vidjelo jedan od glavnih metodičkih i kategorijalnih razloga Marxova sustajanja u kritici političke ekonomije: fokusirajući se na Ricarda, a ne na Smitha, Marxovo se čitanje britanske građanske ekonomije pokazuje bitno nedostatnim.

Otuda se postavlja konkretnije pitanje zašto je Marx podbacio u recepciji smitovske paradigme kao najvišeg dosega britanske političke ekonomije (a uz to i Humea, kao vrhunca klasične britanske političke teorije)?

Odgovor koji nam Strpić nudi ima cirkularni oblik. Da bi shvatio svoje velike prethodnike, Marx je morao shvatiti sebe samoga, jasno razgraničiti metodu i metodologiju svojeg istraživanja spram njihovih. Propustio je to učiniti, misleći da će i bez takva izričitog sučeljavanja već samo njegovo istraživanje na djelu pokazati u čemu su razlike. No svoje veliko istraživanje nije uspio dovršiti, o čemu svjedoči posthumno objavljeni treći svezak Kapitala, koji "karakterizira ambicija da će 'općeniti' analitički instrumentarij naknadno biti razvijen do oblika u kojem će biti

${ }^{16}$ Usp. i nešto oprezniju ocjenu: "Marx uopće ili barem vrlo dugo nije mogao shvatiti Smithovu paradigmu određenja razmjenske vrijednosti, u kojoj nije u prvom planu određivanje veličine vrijednosti (kao kod Ricarda), nego fokusiranje svih tipova društvene povezanosti kroz vrijednost" (Strpić, 2017: 344). 
podoban i za površinsku, konkretiziranu analizu" (ibid.: 239). U toj ambiciji nije uspio, nije uspio izvesti kategorijalni prijelaz iz apstraktne sfere "kapitala općenito" u konkretnu sferu konkurencije, kao "teoriju tržišta i cijena".

Budući da dakle nije uspio cjelovito dovršiti svoj teorijski projekt kritike političke ekonomije, slijedi da su i temeljne kategorije, kao što su roba i vrijednost - razumljive tek iz cjeline izvedbe zbiljskog procesa društvenog kapitala - ostale samo apstraktno pojmovno određene, a ne u punini svojih totalitetom određenih značajki.

Budući da je time cijelo teorijsko zdanje "Kritike" ostalo provizorno, tek prvi apstraktni korak u poimanju predmeta analize, Marx nije mogao previdjeti da ga poteškoće u konkretizaciji znanstvenog aparata onemogućuju da do kraja osvijesti svoju metodu istraživanja i primjerenu strukturu "polu-dijalektičkog" izlaganja.

Cirkularnost je dokaznog postupka očigledna: da je Marx dovršio svoju "Kritiku", primjereno bi mogao shvatiti i svojega velikog prethodnika Adama Smitha; i obrnuto, da je shvatio svojega velikog prethodnika, možda bi i dovršio svoju "Kritiku". Ili, u općenitijoj formulaciji, da je Marx dovršio svoju "Kritiku", primjereno bi mogao shvatiti predmet svoje kritike; i obrnuto, da je shvatio klasičnu političku ekonomiju, možda bi uspio dovršiti svoju kritiku političke ekonomije.

No i da je njegova recepcija klasične političke ekonomije bila potpunija, Marxu to, po Strpićevu sudu, ipak ne bi bilo dovoljno da analitički primjereno izvede "prijelaz" iz apstraktne sfere općenitosti u konkretnu sferu konkurencije. Naime ne samo on nego i cijela klasična politička ekonomija nedovoljno su znali o zbivanjima na "realnom tržištu" i konkurenciji na njemu. Strpić smatra da Marxu "može služiti na čast što je shvatio da je to nedovoljno". Rodio se pola stoljeća prerano i nije se upoznao s "Jevonsovom revolucijom" u političkoj ekonomiji (marginalističkom teorijom korisnosti). ${ }^{17}$ Marx nije bio tip znanstvenika koji "prelazi istraživačke granice empirijsko-analitički korak po korak", nego je bio "tip kreatora novih sinteza na temelju istraživanja koja su učinili drugi, koja treba sistematizirati, dotjerati i skupiti u novu paradigmu" (ibid.: 243).

Strpićeva hermeneutički superiorna kritička rekonstrukcija Marxove analize sadrži bitne i originalne uvide o Marxovim temeljnim kategorijama (ovdje su prikazane samo kategorije "vrijednost" i "roba", čemu bi se u iole opsežnijem prikazu moglo dodati preciziranje kategorija "apstraktni i konkretni rad", "razmjenska i upotrebna vrijednost", "jednostavni i kapitalski promet”, "robna proizvodnja i proizvodnja roba", "robni i kapitalski fetišizam"; uz preciziranje analitičkih granica di-

17 Točnije, teorija vrijednosti granične korisnosti, koja je revolucionirala ekonomiju, vezana je uz imena W. S. Jevonsa (Teorija političke ekonomije, 1871), C. Mengera (Temeljna načela političke ekonomije, 1871) i L. Walrasa (Temelji čiste političke ekonomije, 1874-1877). V. Schumpeter (1975/II: 688-692). 
jalektičke metode). Čime se Marxov Kapital, premda nedovršen, suvereno smješta u znanstvenu povijest kao dostojan nastavak britanske građanske političke ekonomije.

Zapitajmo se završno još jednom, i na temelju Strpićeva kritičkog čitanja marksovske "Kritike", zašto se Marx ograničio samo na prvi svezak Kapitala i odustao od završavanja i objavljivanja cjeline svojih istraživanja. Možda na pravi odgovor upućuje silno važno Strpićevo pojmovno preciziranje kategorije "način proizvodnje": oznaka robna proizvodnja kao način proizvodnje teorijski je plodnija negoli "kapitalski način proizvodnje" ili "način proizvodnje kapitala", a "neusporedivo (je) nadmoćnijom i točnijom kategorijalnom oznakom od 'proleterski' dvoznačnoga 'kapitalističkog načina proizvodnje"” (ibid.: 333; istaknuo - D. L.).

Ako je Marx napredujući u znanstvenom ovladavanju svojim predmetom zastao na prvom svesku Kapitala i odustao od dovršavanja svojega teorijskog sustava, smijemo pretpostaviti da su mu postignuti istraživački rezultati izmicali iz ruku, da mu je sama logika njegova kategorijalnog polja sve neodoljivije pokazivala iluzornost njegova revolucionarnog creda da je epoha kapitala na izmaku. Ako je logika kapitala zapravo logika robne formacije društva i građanske zajednice u cjelini, tada mu nije mogla promaknuti činjenica da epoha robne proizvodnje nipošto nije iscrpljena i da post-robno-kapitalska civilizacija (još) nije na povijesnom obzoru. Znanstvenik u njemu nije mogao odustati od vlastitih istraživačkih uvida, a revolucionar u njemu branio mu je da ih slijedi do kraja. Kada Marx u Kapitalu I (jedinom koji je ako ne teorijski dovršio, a ono objavio) s vremena na vrijeme prekida logiku svojega znanstvenog istraživanja i umeće nestrpljive političke zaključke o "konačnom obračunu s kapitalistima", nisu li ta radikalna politička samoohrabrenja pouzdan indikator da Marx, na svoj užas, shvaća da ga njegov teorijski projekt vodi u odustajanje od kritike političke ekonomije, da ga smješta u glavni tok građanske znanstvene paradigme i politologije kao znanosti građanske zajednice? Kako da čovjek napusti omiljeni životni slogan o promjeni svijeta i kritiku "svega postojećeg" kao svoj projekt, da se svede na "političku ekonomiju kapitala"? Zar da se pomiri s time da sam sebe svrsta među klasike britanske političke ekonomije, što je i bio, po mjerodavnom sudu J. Schumpetera (1975: 324). ${ }^{18}$

Poput Marxa, i Strpića je logička prinuda njegova istraživanja neodoljivo vodila k neočekivanom ishodu: tragajući za Marxom, otkrio je Smitha i Humea, koji će, uz Hobbesa, nakon obrane disertacije u proljeće 1991. biti u trajnome teorijskom fokusu njegovih znanstvenih preokupacija u valorizaciji suvremene relevantnosti klasika građanskoga političkog mišljenja općenito, a političke ekonomije posebice.

18 “Očigledna istina je ta da se Marx, što se tiče čiste teorije, mora smatrati 'klasičnim' ekonomistom i, još uže, članom Ricardove grupe." 
Bilo je logično da je odustao od dovršavanja marksovske "Kritike", uz punu svijest da je Marx, "iako možda osobito važan, samo jedan od putova i samo jedan od ključeva za razumijevanje temeljnih teorija Moderne" (Strpić, 2010b: 10). ${ }^{19}$

Još dvije važne Strpićeve napomene valja barem ukratko komentirati.

Prvo, Strpić opetovano ustvrđuje da kategorijalni aparat Marxove "Kritike" nije operativno primjenjiv u konkretnim analizama. No ipak nije tako. Vidjeli smo kako je još 1982. ocijenio da je djelo Ernesta Mandela Kasni kapitalizam (1981/1972) uspjelo "empirijski dokazati primjenjivost Marxova aparata, takvog kakav je dan u 'Kapitalu', na istraživanje globalnog razvitka reprodukcije kapitala u svijetu i pojedinim zemljama". U ovoj knjizi, barem u fusnoti, ipak nije zaboravio spomenuti Mandela kao "primjer... uspješnog (i, u metodološkom pogledu, sretnog - sretno pogođenog) istraživanja" kakav "predstavljaju Kasni kapitalizam i Kriza 19701974-1978 Ernesta Mandela” (Strpić, 2017: 389). ${ }^{20}$ Nije tako ni sa samim Strpićem, koji je na temelju teorije socijetalnih i političkih ciklusa dijagnosticirao karakter velike svjetske krize 2008. (Strpić, 2008b, 2008c, 2008d).

Drugo, Strpić veoma skrupulozno i sugestivno objašnjava Marxovo odustajanje ili sustajanje u realizaciji vlastitoga preambicioznog teorijskog projekta kao "gotovo nadljudske zadaće". Pa odustaje i sam, ocijenivši da je zadaća možda i neostvariva. Njegovu će pesimističnu prognozu demantirati, premda u drukčijem interpretativnom ključu, francuski filozof Jacques Bidet svojom rekonstrukcijom Marxova projekta i njegovom plodnom ugradnjom u cjelovitu teoriju moderne. Bidet je najprije proveo djelomičnu kritičku rekonstrukciju Kapitala (u Što da se radi $s$ "Kapitalom"?, 1985), na temelju čega je pokušao izvesti i cjelovitu teoriju moderne (Teorija moderne, 1990). Nije u tome uspio, pa je proširio istraživačku zadaću, napose na Habermasovu teoriju "komunikativnog djelovanja", a Marxov teorijski sustav sveo na nezaobilazan, ali ipak samo fragment svoje Opće teorije (1999). Tek je na toj osnovici proveo cjelovitu rekonstrukciju Marxova Kapitala (Objašnje-

19 S uvjerenjem je obrazlagao da glavni klasični doprinos modernoj i suvremenoj političkoj znanosti i društvenim znanostima u cjelini pripada upravo A. Smithu, njegovoj kapitalnoj knjizi Bogatstvo nacija: "Smithov istraživački cilj i ciljani utjecaj još je uvijek postignut (pa, ako je moguće, i 'prepostignut') nakon dva i pol stoljeća! [...] od modernih teoretičara politike nadmašit će ga na koncu vjerojatno samo Thomas Hobbes" (2010b: 148). Otuda i onodobna popularna studentska percepcija o Strpiću kao profesoru "koji se fura na Smitha", koju je sa zadovoljstvom navodio.

${ }^{20}$ S obrazloženjem: "Zahvaljujući tome što se uhvatio 'teorije "dugih valova"” (Schumpeterovih i Kondratievljevih 'velikih ciklusa'), koristeći Marxovu 'cijenu proizvodnje' i njegovo shvaćanje 'ekstra-profita' - Mandel je uspio predvidjeti veliku krizu stagnacije sedamdesetih godina, čije ostatke proživljavamo nejednako po svijetu raspoređene još i u osamdesetima, pa i na početku devedesetih. U to vrijeme... nitko osim njega nije predviđao kraj dugoga poratnoga ekonomskog booma. Ponajmanje na temelju empirijskog istraživanja” (Strpić, 2017: 389). 
nje i rekonstrukcija "Kapitala", 2004). ${ }^{21}$ Time su mu se otvorile plodne mogućnosti za značajna teorijska istraživanja, o čemu svjedoče njegove brojne knjige (2007, 2013, 2014, 2016a, 2016b, 2018) i veoma brojne studije.

Što danas znači čitati Kapital? Davnih dana čitalo ga se "svakodnevno, transparentno, u dramama i snovima naše povijesti, u njenim rasprama i sukobima", s uvjerenjem je isticao Althusser, kategorički pozivajući čitatelje i da "doslovno pročitaju Kapital... Baš sav tekst, četiri knjige, red po red..." (Althusser i Balibar, 1975: 17).

U kontekstu kraja 80-ih, kada je marksizam bio na dnu vala, kada se činilo da se tekst i povijest kapitala posve razmimoilaze, da nam hirovita sudbina izmiče u regresivnom događajnom kontekstu, Dag Strpić provizorno dovršava svoj nedovršivi istraživački projekt čitanja Marxa kao znanstvenoga modernog klasika u veličajnoj egzegezi cijeloga marksovskog opusa u razvojnoj misaonoj liniji britanske klasične političke teorije i političke ekonomije. Čita ga kao što ga nitko čitao nije, uvjereno i uvjerljivo, uvaženim i filozofima i ekonomistima i sociolozima i marksistima usprkos - kao eminentni politolog (baš kao i Hobbesa i Smitha).

Strpićev specifični način čitanja Marxove "Kritike" može se bolje razumjeti ako se psihologijski shvati da je njegovo čitanje politologijski projektirano i ozbiljeno u vrijeme (1975-1991) kada se institucionalno mlada politička znanost u nas borila za svoje puno akademsko priznanje i nastojala emancipirati od predominacije filozofije i ekonomije. Naši profesori filozofi Marxa su čitali u dijalogu s Hegelom (Sutlić, 1967, 1974; Rodin, 1967, 1971, 1974; Prpić, 1976; Burger, 1978), a ekonomisti u sklopu svoje stručnosti (Baletić, 1965; Dragičević, 1957), pri čemu nikome od njih nije moglo ni pasti na pamet da Marxa čita preko Hobbesa, da cjelovito preispita Hegelovu spekulativnu recepciju britanske klasične tradicije političke teorije (Hobbes, Locke, Hume, J. S. Mill, Ferguson) i političke ekonomije (Smith, J. Mill, Petty, Steuart, Ricardo), kao i da kritički valorizira Marxovo sučeljavanje s tom filozofijskom recepcijom. Utoliko se i Strpićev pristup može razumjeti kao prihvaćanje spoznajnog izazova da politologijski pristup Marxovu teorijskom sustavu afirmira kao cjelovit i fundamentalan u odnosu spram parcijalnih pristupa filozofa i čistih ekonomista. Otuda u njegovoj interpretaciji povremeno gotovo prkosno isticanje da je Hobbes prvenstveno politolog, a ne filozof, a Smith prvenstveno politolog, a ne ekonomist, pri čemu, primjerice, u pravilu Hobbesovu Civil philosophy iskazuje kao političku teoriju. ${ }^{22}$

${ }^{21}$ O Strpićevu vrednovanju Bidetova pothvata (trilogije o Marxu, od 1985. do 2004) vidi Strpić, 1989, 2008a (a o vrednovanju Strpićeva vrednovanja vidi Lalović, 2010, 2015).

22 Nije posegnuo za oznakom koju nudi sam Hobbes kada svoju političku teoriju u Levijatanu naziva "doctrines of the POLITIQUES" (Hobbes, 1968: 714; u našem prijevodu: "učenje o politici”, Levijatan, 2004: 453, pogl. 47, t. 34). 
Nije mi poznato da se ijedan politolog, u nas i u svijetu, ikada odvažio upustiti u tako ambiciozan znanstveni projekt dokazivanja da su i Hobbes i Smith klasični politolozi kao teoretičari koji se bave sustavnim politologijskim istraživanjem epohalne građanske radno-razmjenske zajednice. I time pokazao što bi sve politologija mogla biti kada bi se usudila znatno samosvjesnije nego što to uobičajeno čini suočiti s najtežim i najvećim problemima naše epohe. Kako god ocjenjivali Strpićevo znanstveno nasljeđe, nema nikakve dvojbe da je po svojim najvišim dometima regulativno važno za temeljna politologijska istraživanja. Kako iole samosvjestan politolog može ne biti impresioniran takvom iznimnom duhovnom samosviješću?

Riječima kojima je svojedobno Dag Strpić popratio studiju Jacquesa Bideta Što da se radi s "Kapitalom”? (1988) mogu najpregnantnije izraziti priznanje kvalitetama i važnosti Strpićeve teorijske ostavštine u čitanju Marxa: kao ozbiljnom doprinosu znanostima o društvu uopće, koji će, nadao se, "uputiti vjerojatno i mnoge druge istraživače da krenu Bidetovim putem i nastave jednu plodnu teorijsku diskusiju" (Strpić, 1989: 397).

U institucionalnoj povijesti naše hrvatske političke znanosti ne znam za dostojniji spoznajni rezultat i istraživački pothvat od Strpićeva čitanja Marxa, za koji želim vjerovati da će kad-tad dočekati svojega zamišljenoga povlaštenog studenta/ čitatelja, koji će se usuditi kročiti strmim istraživačkim stazama našega vrhunskog politologa.

\section{LITERATURA}

Althusser, Louis/Balibar, Étienne, 1975: Kako čitati Kapital, Centar za kulturnu djelatnost Saveza socijalističke omladine, Zagreb (izvornik: 1971).

Artous, Antoine, 2006: Le fétichisme chez Marx. Le marxisme comme critique sociale, Editions Syllepse, Pariz.

Backhaus, Hans-Georg, 1976: O dijalektici oblika vrijednosti, Marksizam u svetu, 10-11: 185-206 (izvornik: 1969).

Baletić, Zvonimir, 1965: Marksistička teorija ekonomskih kriza, Naprijed, Zagreb.

Bensaïd, Daniel, 1995a: La Discordance des temps. Essais sur les crises, les classes, l'histoire, Éditions de la Passion, Pariz.

Bensaïd, Daniel, 1995b: Marx l'intempestif. Grandeurs et misères d'une aventure critique (XIX-XX siècles), Fayard, Pariz.

Bidet, Jacques, 1988: Što da se radi s "Kapitalom”?, bibl. "Naših tema”, Zagreb (prijevod i pogovor: Dragutin Lalović; izvornik: 1985, 2. izd. 2001). 
Bidet, Jacques, 1990: Théorie de la modernité suivi de Marx et le marché, PUF, Pariz.

Bidet, Jacques, 1999: Théorie générale. Théorie du droit, de l'économie et de la politique, PUF, Pariz.

Bidet, Jacques, 2004: Explication et reconstruction du 'Capital', PUF, Pariz (3. izd. 2015).

Bidet, Jacques, 2008: Opća teorija moderne. Teorija prava, ekonomije i politike, Disput, Zagreb, bibl. "Čari političkoga" (prijevod i bilješka o autoru i djelu: Dragutin Lalović; pogovor: Dag Strpić).

Bidet, Jacques, 2013: L'ÉTAT-monde. Libéralisme, socialisme et communisme à l'échelle globale. Refondation du marxisme, PUF, Pariz.

Bidet, Jacques, 2014: Foucault avec Marx, La Fabrique éditions, Pariz.

Bidet, Jacques, 2016a: Le néolibéralisme. Un autre grand récit, Les Prairies ordinaires, Pariz.

Bidet, Jacques, 2016b: Marx et la Loi travail. Le corps biopolitique du Capital, Les Éditions Sociales, Pariz.

Bidet, Jacques, 2016c: Le Capital lu par Moishe Postone: alchimie ou astrologie?, Revue de philosophie économique (objavljeno 2017. pod novim naslovom "Misère de la philosophie marxiste: Moishe Postone lecteur du Capital", u revueperiode.net; engleska verzija: "Marx's Capital as Read by Moishe Postone: Alchemy or Astrology?", Continental Thought and Theory).

Bidet, Jacques, 2018: "Eux" et "nous". Une alternative au populisme de gauche, Éditions Kimé, Pariz.

Bidet, Jacques/Duménil, Gérard, 2007: Altermarxisme. Un autre marxisme pour un autre monde, PUF, Pariz.

Burger, Hotimir, 1978: Znanost povijesti: problem znanosti u Marxovu djelu, CKD, Zagreb.

Dragičević, Adolf, 1957: Potrebni rad i višak rada, Kultura, Zagreb.

Duménil, Gérard, 1978: La loi économique dans “Le Capital”, François Maspero, Pariz (s predgovorom Louisa Althussera).

Foisneau, Luc, 2016: Hobbes. La vie inquiète, Éditions Gallimard, Pariz.

Foucault, Michel, 1997: "Il faut défendre la société". Cours au Collège de France 1976, Éditions Gallimard, Pariz.

Hobbes, Thomas, 1968: Leviathan, Penguin Books (izdanje priredio C. B. Macpherson). Hobbes, Thomas, 2004: Levijatan, Jesenski i Turk, Zagreb.

Hribar, Tine, 1983: Metoda Marxovega Kapitala, Cankarjeva založba, Ljubljana.

Jappe, Anselm, 2003: Les aventures de la marchandise. Pour une nouvelle critique de la valeur, Denöel, Pariz (novo izd. 2017). 
Jappe, Anselm, 2012: Kurz, voyage au coeur des ténèbres du capitalisme (recenzija knjiga R. Kurza Vies et mort du capitalisme, 2011. i Geld ohne Wert. Grundrisse zu einer Transformation der Kritik de politischen Ökonomie, 2012).

Kolm, Serge-Christophe, 1986: Philosophie de l'économie, Éditions du Seuil, Pariz.

Krisis (grupa: Kurz, Robert/Lohoff, Ernst/Trenkle, Norbert), 2002: Manifeste contre le travail, Éditions Léo Scheer, Pariz (izvornik: 1999).

Kurz, Robert, 1991: Der Kollaps der Modernisierung: Vom Zusammenbruch des Kasernensozialismus zur Krise der Weltokonomie, Eichborn, Frankfurt am Main.

Kurz, Robert, 1999: Schwarzbuch Kapitalismus - Ein Abgesang auf die Marktwirtschaft, Eichborn, Frankfurt am Main.

Kurz, Robert, 2002a: Lire Marx. Les principaux textes pour le XXIe siècle, Éditions les Balustres, Pariz (izvornik: 2000).

Kurz, Robert, 2002b: Le boom de la modernité. Les armes à feu comme moteur du progrès technique, la guerre comme moteur de l'expansion: retour sur les origines du travail abstrait, Jungle World; dostupno na: www.exit-online.org; posjećeno: 10. 4. 2020.

Kurz, Robert, 2010: Le double Marx, dostupno na: www.palim-psao-fr > article-le-double-Marx, par-Robert-Kurz-1205386; posjećeno: 25. 2. 2020.

Kurz, Robert, 2011: Vies et mort du capitalisme. Croniques de la crise, Nouvelles Éditions, Pariz.

Kurz, Robert, 2015: La fin de la politique, Cités 64: 93-110; dostupno na: /1/48/88/ 48/20160429/ob_cdac15_kurz-fin-de-la-politique.pdf

Kurz, Robert, 2019: La substance du capital, Éditions L'Échappé, Pariz (ogledi izvorno objavljeni 2004. i 2005).

Lalović, Dragutin, 2006a: U Hobbesovoj zamci: pojam suverenosti?, Politička misao (43) $1: 3-27$.

Lalović, Dragutin, 2006b: Habemus Levijatan?, Politička misao (43) 1: 115-136.

Lalović, Dragutin, 2006c: Mogućnosti političkoga, Disput, Zagreb.

Lalović, Dragutin, 2008a: Države na kušnji, NZCH/Disput, Zagreb.

Lalović, Dragutin, 2008b: Zdvojna posebnost u raljama ohole općenitosti?: politologija kao znanost i politolog kao stručnjak, Anali Hrvatskog politološkog društva 2008 (5): 117-144.

Lalović, Dragutin, 2009: Što da se radi s Levijatanom?, Politička misao (46) 2: 47-68.

Lalović, Dragutin, 2010: O umijeću čitanja Marxova Kapitala. Dag Strpić - Jacques Bidet, Politička misao (47) 4: 50-70.

Lalović, Dragutin, 2012: Povratak Marxa, povratak Marxu?, Politička misao (49) 1: 233248.

Lalović, Dragutin, 2015: Maître-penseur razvojne politologije, pogovor knjizi: Dag Strpić, Prema Novoj političkoj ekonomiji, Disput, Zagreb: 263-302. 
Lalović, Dragutin, 2017a: Marxovo nasljeđe kao zadaća mišljenja, pogovor knjizi Strpić, Dag, 2017: Robna proizvodnja i udruženi rad u Marxovoj kritici političke ekonomije, Disput, Zagreb: 439-484.

Lalović, Dragutin, 2017b: Republican Synthesis of the Political and of the State in Rousseau's Political Theory, u: Vujeva, Domagoj/Ribarević, Luka (ur.): Europe and the Heritage of Modernity, Disput, Zagreb: 55-94.

Lohoff, Ernst/Trenkle, Norbert, 2012: Die Große Entwertung: Warum Spekulation und Staatsverschuldung nicht die Ursache der Krise sind, Unrast, Münster.

Macpherson, Crawford Brough, 1968: Predgovor, u: Hobbes, Leviathan, Penguin, Harmondsworth.

Macpherson, Crawford Brough, 1981: Politička teorija posjedničkog individualizma, CDD RSSOH, Zagreb (izvornik: 1962).

Mandel, Ernst, 1981: Kasni kapitalizam, Centar za kulturnu djelatnost SSOH, Zagreb (izvornik: 1972).

Marx, Karl/Engels, Friedrich, 1968-1979: Dela, Institut za međunarodni radnički pokret/ Prosveta, sv. 1-46; sv. 47, knjiga registara, 1987; navode se kao: $M E D$, s oznakom sveska i stranice).

Marx, Karl, 1974: Kapital I, u: MED, sv. 21, Prosveta/Institut za izučavanje radničkog pokreta, Beograd.

Marx, Karl, 1974a: Bijeda filozofije, u: MED, sv. 7, Prosveta/Institut za izučavanje radničkog pokreta, Beograd.

Marx, Karl, 1977a: Kapital II, u: MED, sv. 22, Prosveta/Institut za izučavanje radničkog pokreta, Beograd.

Marx, Karl, 1977b: Kapital III, u: MED, sv. 23, Prosveta/Institut za izučavanje radničkog pokreta, Beograd.

Marx, Karl, 1979: Osnovi kritike političke ekonomije, u: MED, sv. 19, Prosveta/Institut za izučavanje radničkog pokreta, Beograd.

Meštrović, Matko, 2018: Do kuda? Do kada?, Hrvatska sveučilišna naklada, Zagreb.

Ollman, Bertel, 2005: La dialectique mise en oeuvre, Editions Syllepse, Pariz.

Osier, Jean-Pierre, 1976: Thomas Hodgskin, une critique prolétarienne de l'économie politique, François Maspero, Pariz.

Pocock, J. G. A., 1975: The Machiavellian Moment. Florentine Political Thought and the Atlantic Republican Tradition, Princeton University Press, Princeton/London.

Polanyi, Karl, 1999: Velika preobrazba. Politički i ekonomski izvori našeg vremena, Naklada Jesenski i Turk, Zagreb.

Postone, Moishe, 2009: Temps, travail et domination sociale. Une réinterpretation de la théorie de Marx, Mille et une nuits, Pariz. 
Prpić, Ivan, 1976: Država i društvo. Odnos "građanskog društva" i "političke države" u ranim radovima Karla Marxa, Mala edicija "Ideja”, Beograd.

Reichelt, Helmut, 1970: Zur logischen Struktur des Kapitalbegriffs bei Karl Marx, Europäische Verlagsanstalt, Freiburg (2. izd. 2001).

Reichelt, Helmut, 2008: Neue Marx Lektüre - Zur Kritik sozialwissenschaftlicher Logik, VSA Verlag, Hamburg.

Ribarević, Luka, 2016: Hobbesov moment: rađanje države, Disput, Zagreb (bibl. "Čari političkoga").

Rodin, Davor, 1967: Aspekti odnosa Hegelove i Marxove dijalektike, IDN, Zagreb.

Rodin, Davor, 1971: Dijalektika građanskog društva, Nolit, Beograd.

Rodin, Davor, 1974: Marxova misao zajednice, Mladost, Beograd.

Rosdolsky, Roman, 1975: Prilog povijesti nastajanja Marxova "Kapitala”, sv. I-II, Izdavački centar "Komunist”, Beograd (izvornik: 1968).

Rubin, Isaak Iljič, 1978: Ogledi o Marxovoj teoriji vrijednosti, Stvarnost, Zagreb (izvornik: 1928).

Scholz, Roswitha, 2001: Das Geschlecht des Kapitalismus. Feministische Theorie und die postmoderne Metamorphose des Patriarchats, Horlemann Verlag, Bonn.

Schumpeter, Joseph A., 1975: Povijest ekonomske analize, I-II, Informator, Zagreb.

Schwartz, Winfried, 1978: Vom Rohentwurf zum Kapital. Die Strukturgeschichte des Marxschen Hauptwerkes, Verlag Das Europäische Buch, Berlin (West).

Skinner, Quentin, 1989: The State, u: Ball, H./Hanson, R. I. (ur.): Political Innovation and Conceptual Change, Cambridge University Press, Cambridge: 90-131; pretisak 1997: Goodin, Robert E./Pettit, Philip (ur.): Contemporary Political Philosophy. An Anthology, Blackwell Publishers, Oxford \& Cambridge: 3-26; dorađena verzija: 2002: Visions of Politics, sv. II: Rennaissance Virtue, pogl. 14: "From the state of princes to the person of the state", Cambridge University Press, Cambridge: 268413.

Strauss, Leo, 1965: Natural Right and History, The University of Chicago Press, Chicago/London (1. izd. 1953).

Strauss, Leo, 1971: Prirodno pravo i istorija, "Veselin Masleša", Sarajevo (bibl. "Logos").

Strauss, Leo/Cropsey, Joseph (ur.), 2006: Povijest političke filozofije, Golden marketing/ Tehnička knjiga, Zagreb (prema izdanju iz 1987; 1. izd. 1963).

Strpić, Dag, 1975a: Model profesora Koraća I, Pitanja (7) 1-2: 69-76.

Strpić, Dag, 1975b: Marx i robna proizvodnja u socijalizmu, Pitanja (7) 9-10: 79-90.

Strpić, Dag, 1976: Neke metodološke napomene uz razmatranje oblika djelovanja zakona vrijednosti u socijalizmu, Pitanja (8) 3-4: 56-71. 
Strpić, Dag, 1982: Intervencija na znanstvenom simpoziju "Moša Pijade i aktualnost Marxova Kapitala", u: Cvjetičanin, Veljko/Bogdanović, Sava (ur.): Aktualnost Marxova "Kapitala", Radničko i narodno sveučilište "Moša Pijade", Zagreb: 134147.

Strpić, Dag, 1983a: Na tlu kapitala, Naše teme (27) 5: 649-656.

Strpić, Dag, 1983b: Kapital-odnos i "etatizam” u socijalizmu, Pogledi (13) 2: 152-177.

Strpić, Dag, 1983c: "Potiskivanje" "ekonomskih zakonitosti", Socijalizam (26) 7/8: 1015-1030.

Strpić, Dag, 1984: Elementi Bakarićeva marksizma, Pogledi (14) 3: 163-190 (pretisak: Stipe Pojatina (ur.), 1985: Društvena reprodukcija u djelu Vladimira Bakarića, Centar CK SKH za idejno-teorijski rad "Vladimir Bakarić"/Globus, Zagreb: 50-91).

Strpić, Dag, 1985a: Društveno vlasništvo, Socijalizam 4.

Strpić, Dag, 1985b: Politička ekonomija socijalizma, u: Pjanić, Zoran (ur.): Kritički o kritici političke ekonomije, Centar za idejno-teorijski rad GK SKH etc., Zagreb.

Strpić, Dag, 1986a: U potrazi za teorijskom osnovom (Za izradu analitičkog instrumentarija istraživanja ekonomskih zakonitosti), Naše teme (30) 1-2: 76-103.

Strpić, Dag, 1986b: Uz kritiku političke ekonomije, Naše teme (30) 10-11: 1581-1604.

Strpić, Dag, 1988a: Obrazovanje, tehnološki i društveni razvoj i društvena infrastruktura, Naše teme (32) 1-2: 24-42.

Strpić, Dag, 1988b: Kapital i rad u SFRJ - teze, Naše teme (32) 6: 1320-1328.

Strpić, Dag, 1988c: Udruženi rad, privatno i društveno vlasništvo, Naše teme (32) 7-8: 1841-1851.

Strpić, Dag, 1989: Tržišna ili robna formacija/proizvodnja društva?, Naše teme (33) 3: 397-412.

Strpić, Dag, 1998: Promjena. Politička i političko-ekonomska promjena od Hobbesa do Hayeka. Uvodne studije, FPZ-Politička misao, Zagreb.

Strpić, Dag, 2008a: Marx koji nedostaje, pogovor knjizi: Bidet, Jacques, 2008a: Opća teorija moderne. Teorija prava, ekonomije i politike, Disput, Zagreb: 365-382.

Strpić Dag, 2008b: Razvojna politologija i politike razvoja: Političko i razvojno harmoniziranje te ciklička sinergija javnih politika, Anali Hrvatskog politološkog društva 2008 (5): 211-240.

Strpić, Dag, 2008c: Službena znanost 2008: riječ je o saniranju moderne države i društva u cjelini. Ne tek o par bilijardi dolara, Novi list, 1. 10.

Strpić, Dag, 2008d: Promjena paradigme: Samo fundamentalno znanstveno utemeljena promjena razvojnih strategija može biti spas, Novi list, 22. 10.

Strpić, Dag, 2009: Moderna normala: Kontekstualne teorijske osnove političke analize socijetalnih ciklusa i kriza u Matrix-kapitalizmu, Politička misao (46) 3: 7-38.

Strpić, Dag, 2010a: Ciklusi moderne normale, Politička misao (47) 4: 11-29. 
Strpić, Dag, 2010b: Karl Marx i politička ekonomija Moderne, NZCH/Disput, Zagreb (bibl. "Luča").

Strpić, Dag, 2015: Prema Novoj političkoj ekonomiji, Disput, Zagreb (priredio: D. Lalović).

Strpić, Dag, 2017: Robna proizvodnja i udruženi rad u Marxovoj kritici političke ekonomije, Disput, Zagreb.

Sutlić, Vanja, 1967: Bit i suvremenost. S Marxom na putu k povijesnom mišljenju, "Veselin Masleša", Sarajevo (bibl. "Logos").

Sutlić, Vanja, 1974: Praksa rada kao znanost povijesti. Ogledi uz filozofijsko ustrojstvo Marxove misli, Kulturni radnik, Zagreb.

Tombazos, Stavros, 1994: Le temps dans l'analyse économique: les catégories du temps dans le "Capital", Cahiers des saisons, Pariz (engleski prijevod: Time in Marx: The Categories of Time in Marx's Capital, Haymarket Books, Chicago, 2014).

Tombazos, Stavros, 2020: Crise mondiale et reproduction du capital, Editions Syllepse, Pariz.

Zarka, Yves Charles, 1995: Hobbes et la pensée politique moderne, PUF, Pariz (2. izd. 2001; 3. izd. 2012).

Zarka, Yves Charles, 1999: La décision métaphysique de Hobbes. Conditions de la politique, J. Vrin, Pariz (1. izd. 1987).

Žagar, Davorin, 2019: Machiavellijevo poimanje političkoga, Fakultet političkih znanosti, Zagreb (neobjavljena doktorska disertacija).

Dragutin Lalović

\title{
ALONG THE STEEP PATHWAYS OF POLITICAL SCIENTIST DAG STRPIĆ IN THE READING OF MARX
}

\begin{abstract}
Summary
The text delineates and evaluates the principal features of the scientific approach, mode of argumentation and the possible scope of Strpić's theoretical legacy in terms of research and analysis as well as the development of society in general. In particular, the focus is on his fundamental research of Marx's epochal critique of political economy, presented primarily in the book Commodity Production and Associated Labour in Marx's Critique of Political Economy (2017/1991). First of all, an account is given of Strpić's initial programme of research into contemporary Marxian completing and developing of Marx's "Critique" (1981/1982). The central point of the exposé is a concise overview of the main elements of Strpić's reading of Marx's critique of political economy. The first element is an evaluation of Marx's reception
\end{abstract}


of classical British political theory and political economy, and of the reception of this legacy in Hegel's philosophy. The second is a reconstruction of the logic of Marx's apparatus of categories as the abstract sphere of "capital in general", in distinction to the concrete sphere of competition between "many capitals", and, within that field of research, an adequate definition of "commodity in general" as a logical starting point of the entire theoretical system and of value as law of fluctuation of market prices. Thirdly, it is apt to approach The Capital from the dynamic perspective of the theory of societal cycles and cyclical development; the tendency laws of historical development of capitalist accumulation must lead to the understanding of the structure of capital as a social process of production, circulation and reproduction. The fourth element is differentiation between the Marxian (scientific and critical) and the Marxist (ideological and class-based) approaches to the critique of political economy. This is followed by a detailed account and critical evaluation of Strpić's intriguing view on the duality of classical political theories, which, in his judgment, is manifest as a distinction between Machiavelli's "politicology", which perceives politics in terms of power and ruling, and Hobbes's "politology", as systematic science of the civil community (Common-wealth). This then is the basis of an inquiry into Strpić's Hobbesian politological understanding of Marx. In the final section, an attempt is made to discern the reasons for Marx's failure to finish the project of political economy critique, which is why his interpreters are faced with almost insurmountable theoretical obstacles in their effort to develop Marx's scientific legacy into a possible foundation of contemporary theoretical and empirical research of the major problems of our time.

Keywords: Critique of Political Economy, Political Science, Marxism, Marx, Hobbes, Strpić

Dragutin Lalović je profesor Fakulteta političkih znanosti u miru.

Kontakt: Dragutin Lalović, Slavka Kolara 21, 10410 Velika Gorica. E-mail: dragan.lalovic5@gmail.com 